NBER WORKING PAPER SERIES

\title{
CHANGES OVER TIME IN UNION RELATIVE \\ WAGE EFFECTS IN THE UK \\ AND THE US REVISITED
}

David G. Blanchflower

Alex Bryson

Working Paper 9395

http://www.nber.org/papers/w9395

\author{
NATIONAL BUREAU OF ECONOMIC RESEARCH \\ 1050 Massachusetts Avenue \\ Cambridge, MA 02138
}

December 2002

We thank John Addison, Dan Feenberg, Barry Hirsch, David Metcalf and Mark Wooden for helpful discussions and John Addison also for encouraging us to write this chapter. We wish to thank the Economic and Social Research Council for their financial assistance (grant R000223958). We thank the BSAS team - particularly Katarina Thomson - at the National Centre for Social Research for providing the BSAS data. We acknowledge the Department of Trade and Industry, the Economic and Social Research Council, the Advisory, Conciliation and Arbitration Service and the Policy Studies Institute as the originators of the 1998 Workplace Employee Relations Survey data, and the Data Archive at the University of Essex as the distributor of the WERS data. None of these organisations or individuals bears any responsibility for the authors' analysis and interpretations of the data. The views expressed herein are those of the authors and not necessarily those of the National Bureau of Economic Research.

(C) 2002 by David G. Blanchflower and Alex Bryson. All rights reserved. Short sections of text not to exceed two paragraphs, may be quoted without explicit permission provided that full credit including, (C) notice, is given to the source. 
Changes over time in union relative wage effects in the UK and the US revisited David G. Blanchflower and Alex Bryson

NBER Working Paper No. 9395

December 2002

JEL No. J3, J5

\begin{abstract}
This paper examines the impact of trade unions in the US and the UK and elsewhere. In both the US and the UK, despite declining membership numbers, unions are able to raise wages substantially over the equivalent non-union wage. Unions in other countries, such as Australia, Austria, Brazil, Canada, Chile, Cyprus, Denmark, Japan, New Zealand, Norway, Portugal and Spain, are also able to raise wages by significant amounts. In countries where union wage settlements frequently spill over into the non-union sector (e.g. France, Germany, Italy, the Netherlands and Sweden) there is no significant union wage differential. The estimates from the seventeen countries we examined averages out at 12 per cent.

Time series evidence from both the US and the UK suggests three interesting findings. First, the union differential in the US is higher on average than that found in the UK (18 per cent compared with 10 per cent). Second, the union wage premium in both countries was untrended in the years up to the mid-1990s. Third, in both countries the wage premium has fallen in the boom years since 1994/95. It is too early to tell whether the onset of a downturn in 2002 will cause the differential to rise again or whether there is a trend change in the impact of unions. It is our view that most likely what has happened is that the tightening of the labor market has resulted in a temporary decline in the size of the union wage premium. Time will tell whether the current loosening of the labor market, that is occurring in both countries, will return the union wage premium to its long run values of 10 per cent in the case of the UK and 18 per cent in the case of the US. On the basis of past experience it seems likely that they will.
\end{abstract}

David Blanchflower

Department of Economics

Dartmouth College

Hanover, NH 03755

and NBER

blanchflower@dartmouth.edu
Alex Bryson

Policy Studies Institute

100 Park Village East

London NW1 3SR

a.bryson@psi.org.uk 


\section{Introduction}

Union density has been in decline in the United States and Britain for two decades now (Appendix Table 1). It is often asserted by commentators that trade unions are outmoded institutions, shunned by employers and unable to reach a new generation of workers imbued with individualist values that are at odds with the ethos underpinning unionism. But the propensity of individuals to join unions is not simply a question of "desire" or ideological commitment. More broadly, one can think of union membership as a good - a product or service to be purchased. Employees derive utility from this good, as they would other services or products. In the case of union membership, this utility can be psychological. For example, the decision to purchase membership may be due to the desire to conform to a social norm and thus maintain one's reputation among co-workers. It may also be driven by instrumentalism, wherein employees think they have something tangible to gain from membership, either in terms of better wages, improved non-pecuniary terms of employment, or they may see it as insurance against arbitrary employer actions. So, benefits may accrue to the individual, but they come at a cost. Employees will purchase membership if the benefits outweigh the costs. A shift in the propensity to purchase union membership may reflect a shift in individuals' perceptions of the costs and benefits attached to membership. It does appear though that the cost of union membership is generally low. Reynolds, Masters, and Moser $(1999$, p. 406) estimate that the fee required for membership is equivalent to roughly two hours' pay per month while the cost of industrial action accounts for less than 1 per cent of working time for the typical union worker. Neither has risen substantially over time.

What of the benefits of membership? Perhaps the most visible and most significant is the union wage premium or wage gap. The most obvious way of measuring the value of union 
membership to employees is to estimate the extent to which members' wages are higher than those of similar non-members. This union wage premium arises because unions bargain on members' behalf for wages that are above the market rate. In the literature what is usually estimated is the difference between the ceteris paribus earnings of union members and those of non-members. That is, how much would wages change if an individual moved from non-union to union status or vice-versa, holding constant their individual and workplace characteristics. There has been speculation that the intensification of competition since the 1980 s, coupled with a diminution of union bargaining strength, has prevented unions from obtaining the sort of wage premium they achieved in the past. This is the issue we investigate in this chapter.

If the costs of membership have remained constant or risen, while the wage benefits of membership have fallen, this might help explain the reticence of employees to join unions. However, evidence to date is only suggestive of a declining union wage premium: there are few studies estimating the union wage premium with consistent time-series data and recent studies use techniques which were not used in earlier analyses. This gap in the evidence is filled by the remainder of this paper. In particular, we consider how much the premium varies by country, across groups and through time. These issues are examined using broadly comparable time series data for the United States and the United Kingdom ${ }^{1}$. The evidence suggests that there has been some constancy in the premium for most of the post-war years in both countries, although the level of the differential has been somewhat higher in the US than in the UK. We find evidence that the union wage premium has declined steadily in both countries since the mid1990s as the economies entered unprecedented boom periods and labour markets tightened dramatically $^{2}$. In addition, some evidence is presented on the size of the wage premium in seventeen other countries drawn from three continents - Australia, Austria, Brazil, Canada, 
Chile, Cyprus, Denmark, France, Germany, Italy, Japan, Netherlands, New Zealand, Norway, Portugal, Spain and Sweden.

\section{Background}

There are two ways unions can affect wages in the economy (Farber, 2001). The first is the direct effect on the wages of workers in jobs where wages are set through collective bargaining. This may affect non-members' and members' wages. The second level is the impact that the presence of unions has in the economy: this can change the level and distribution of wages generally. In theory, these general equilibrium effects may both raise and reduce the level of aggregate wages in the economy. Since it is not possible to observe the counterfactual (wages in the absence of unions) this union effect is not easily estimable. The union-non-union wage differential (the wage gap), defined as

$$
\Delta=\frac{W_{u}-W_{n}}{W_{n}},
$$

is estimable because we observe the wages of members $\left(W_{u}\right)$ and non-members $\left(W_{n}\right)$. Provided differentials are small, this expression is usefully approximated by

$$
\Delta \approx \Delta_{u}-\Delta_{n}
$$

which says that the measured union wage gap is approximately equal to the difference in the proportional effects of unions on the union and non-union wage. The union wage gap in equation (1) can be usefully approximated by the difference in log wages, implying that

$$
\Delta \approx \ln \left(W_{u}\right)-\ln \left(W_{n}\right)
$$

The union wage gap may reflect the direct effect of unions on the wages of unionised workers, and the offsetting effects on non-union workers. Of course, there may be endogenous selection into union status arising for two reasons. First, there is "worker choice" in which 
workers only choose membership if the union wage is greater than the wage available to the individual outside the union. It is often assumed that workers with a lower underlying earning capacity have more to gain from membership than higher quality workers, in which case this selection process will understate the union wage premium. The second selection process arises through "queuing", since not all workers desiring union employment can find union jobs. Under this model, union employers may choose the best of the workers among those desirous of a union job. This employer selection implies a positive bias in the union premium but, a priori, it is not clear whether this bias is greater or less than the negative bias implied by worker selection. Either way, if there is endogenous selection the membership mark up estimated using standard cross-sectional regression techniques 'can be interpreted as the average difference in wages between union and non-union workers, but it can not be interpreted as the effect of union membership on the wage of a particular worker' (Farber, 2001, p. 11).

Causal inference is problematic because, where workers who become members differ systematically from those who do not become members in ways which might affect their earnings, independent of membership, we cannot infer the non-union wage for union members simply by comparing union members' wages with those of non-members. In the literature for the United States, the problem of selection bias is usually tackled by modelling union status determination simultaneously with earnings and estimating an econometric model that takes account of the simultaneity. This usually involves a Heckman estimator where the earnings function and union status determination function are assumed to have errors that are jointly normal. This technique relies on untestable exclusion restrictions whereby variables assumed to affect union status have no direct effect on earnings. In his review of the literature, H. Gregg Lewis (1986) concluded that, because of these arbitrary functional form assumptions and 
untestable exclusion restrictions, results from these studies were unreliable. Estimates of the union wage gap using simultaneous equation methods tend to produce large and unstable estimates. Panel estimates, which involve making use of data on the same individuals over time and observing how wages change as individuals alter their union status have problems of misclassification and measurement error which tend to result in estimates of the impact of unions that are downward biased. Lewis (1986) takes the view that the most appropriate way to estimate the impact of unions on wages is using OLS. He suggests OLS may produce an upper bound estimate of the true impact of unions because 'such estimates suffer from upward bias resulting from the omission of control variables correlated with the union status variable' (Lewis, 1986, p. 9). The assumption is that some of the wage gap attributed to union membership is, in fact, attributable in part to the characteristics of members, their jobs and their employers which would give them higher wages than non-members in any case. In practice, as we note above and as other studies indicate (Farber, 2001; Robinson, 1989), bias in cross-sectional OLS estimation due to unobserved heterogeneity may both upwardly or downwardly bias the "true" impact". Here, our primary concern is with changes in the union wage premium over time. We do not seek to control for the potential endogeneity of union membership. Rather, we adopt the standard approach to estimation of the union-non-union wage gap using individual-level data and estimating by OLS. That is,

$$
\ln \mathrm{W}_{\mathrm{it}}=\mathrm{X}_{\mathrm{it}} \beta+\delta \mathrm{U}_{\mathrm{it}}+\varepsilon_{\mathrm{it}}
$$

where subscript it indexes individuals over time, $X_{i t}$ is a vector of worker, job and workplace characteristics, $U_{i t}$ is a dummy variable indicating union membership, and $\varepsilon_{i t}$ is a random component. The parameter $\delta$ represents the average proportional difference in wages between union and non-union workers adjusted for worker and workplace characteristics, and it is the 
regression-adjusted analogue of $\Delta$. In our work, we assume that any bias in our estimates of the $\delta$ over time arising through unobserved heterogeneity remains constant over time.

The vast majority of work estimating the effects of union membership on relative wages has been based on US data. The definitive empirical works in this area are by H. Gregg Lewis, $(1963,1986)$, the father figure of this literature ${ }^{4}$. The first of his two books measured the effects of unions using relatively aggregated data at the industry level, backed up by case study evidence. In the 1986 volume, Lewis examined approximately 200 studies that had used microdata to estimate the effect of unions. He concluded that it was not possible to use "macro" data to estimate the union wage gap and that methodologically estimating an Ordinary Least Squares (OLS) equation with wages on the left, and union status on the right with a group of controls, was probably the best way to estimate the size of the effect. Panel estimates had problems of misclassification and measurement error while simultaneous equation methods suffered from poor identification due to a lack of suitable instruments. Lewis (1986) found that the overall impact of unions in the US economy was approximately 15 per cent and showed relatively little variation across years - varying between 12 per cent and 19 per cent between 1967 and 1979 .

Subsequent work confirmed constancy of the differential until the 1990s. For example, Hirsch and his co-authors have produced a series of papers estimating changes in the differential over time and concluded there has been some decline in the premium in recent years (e.g. Hirsch, Macpherson and Schumacher, 2002; Hirsch and Schumacher, 2002; Hirsch and Macpherson, 2002). Bratsberg and Ragan (2002) examine the trend in the private sector union wage differential in the US, 1971-99, and conclude that dispersion in the wage premium across industries has substantially declined as the US economy has become more competitive but that there has been only a modest decline in the average premium. Bratsberg and Ragan confirmed 
the stability of the premium over time, as noted in Linneman, Wachter and Carter (1990), but did observe some evidence of a decline in the premium at the end of the 1990s.

There are reasons to believe that the union wage gap might vary with the business cycle. If the union premium comes from employers sharing rents, it is plausible that the premium will be higher when those rents are higher, in which case the wage gap would be pro-cyclical. Alternatively, unions may insulate their members from the downward wage pressures workers in general face in more difficult times, in which case the wage gap may be counter-cyclical. In an interesting paper, Grant (2001) used panel data on individuals from the CPS from 1975 to 1993 to examine the cyclicality of union and non-union wages over time. He found that the union coefficients in the non-union sector for the two periods 1975-81 and 1983-93 were always procyclical and generally similar in the two periods. In contrast in the union sector Grant found strong procyclicality in the first period, confirming earlier evidence in Moore and Raisian (1980), but weak or no procyclicality in the union sector in the second period. We come back to this issue later since we find evidence of a counter-cyclical wage gap in the US and UK in the 1990s.

Raphael (2000) used a sample of workers displaced by plant closings from the 1994 and 1996 Current Population Survey Displaced Workers Supplement files to estimate the effects of union membership on weekly earnings. When models were estimated using the entire sample of displaced workers, longitudinal estimates of the union earnings effect were found to be similar in magnitude to estimates from cross-sectional regressions. In models estimated separately by skill group, the author found some evidence of positive selection into unions among workers with low observed skills and negative selection into unions among workers with high observed skills. Finally, Wunnava and Okunade (1996) used data for men from the Panel Survey of Income 
Dynamics and found an overall union wage premium of about 12 per cent for the 1980 s, which is a good deal lower than reported in most other studies and possibly driven by measurement error in the union status variable. In response to fluctuations in local labour market conditions, proxied by the local unemployment rate, they found a much more flexible wage-setting process in the non-union sector relative to the union sector. The long-term effect of unemployment on non-union real wages suggested an approximate 0.6 per cent decline for every one percentage point increase in unemployment, but the long-term effect of unemployment on real wages of union members was negligible. Wunnava and Okunade's estimates of the union wage premium ranged between 11.6 to 12.3 per cent for the sample period. Union wages were found to be insensitive to short-run fluctuations in local labour market conditions, and counter-cyclical in nature.

In the UK there have been approximately thirty studies, some based on establishment data $^{5}$ and others on individual data (including some using linked employer-employee data) ${ }^{6}$. It needs to be pointed out at the outset that industrial relations are rather more complex in Britain than they are in the United States. For example, in Britain many more non-members work in workplaces that are covered by union agreements and, conversely, more union members are employed in workplaces where unions are not engaged in pay bargaining than is true for the US. There is, correspondingly, a multi-faceted literature in the UK which has investigated the free rider problem (see Booth and, Bryan, 2001; Hildreth, 2000) as well as the importance of union recognition (Blanchflower, 1984; 1986), multiple unionism (Machin, Stewart and van Reenen, 1993) and closed shops (Stewart, 1987; Blanchflower, Garrett and Oswald. 1989; Metcalf and Stewart, 1992). (There are one or two papers in the US also on the role of coverage, including Budd and Na, 2000, and Schumacher, 1999.) Because we are interested in the benefits accruing 
to individuals through their membership, this is not the path we will follow here: our main focus is a comparative one involving the benefits of union membership on wages.

The recent spate of studies that have looked at the impact of union membership on wages has been occasioned by a growing belief that the union wage premium may be falling in Britain. Some argue that a decline in the average union premium is consistent with diminishing union influence over pay setting. There is certainly evidence pointing in that direction. First, case studies suggest the scope of bargaining has narrowed substantially in companies that continue to bargain with unions (Brown et al., 1998). Second, pay settlements in the private sector during 1997/98 were no greater where trade unions were involved than in their absence (Forth and Millward, 2000b). Third, even where managers say employees have their pay set through workplace-level or organisation-level collective bargaining, union representatives and officials are either not involved or are only consulted in a substantial minority of cases (Millward, Forth and Bryson, 2001). But there is also evidence to the contrary. For example, unions continue to have a substantial effect on pay structures, bringing up the wages of the lowest paid and thus narrowing pay differentials across gender, ethnicity, health and occupation (Metcalf, Hansen, and Charlwood, 2001). These studies, which indicate union effects despite substantial declines in union density, might suggest that those unions that have survived are the stronger and, as such, better able to command a wage premium (thus raising the "batting average" of unions). Here we briefly review what studies to date have told us about the size of the union wage premium over time and across workers.

The consensus in the earlier literature was that the mean union wage gap was approximately 10 per cent (Blanchflower, 1999). Despite the rapid decline in union density experienced in the UK since 1979, there was evidence to suggest that the gap remained roughly 
constant from 1970 - the year for which the earliest estimate is available (Shah, 1984) - to 1995 (see Blanchflower, 1999). However, there is some dispute on this question, with some studies pointing to trends in either direction. For instance, establishment-level analyses indicated that the union wage premium in the early 1980s was most evident where unions were strong, as indicated by the presence of a closed shop (Stewart, 1987). This premium seems to have declined in the second half of the 1980s, a trend which has been attributed to a decline in the incidence and impact of the closed shop, coupled with unions' inability to establish differentials in new workplaces (Stewart, 1995). On the other hand, Andrews, Bell and Upward (1998) find the bargaining coverage differential over the period 1975-1994 moved counter-cyclically, with an underlying upward trend which they attribute to the decentralisation of pay bargaining. In addition to cross-sectional estimates, there has been a series of papers producing estimates for this period based on longitudinal data for Britain using the British Household Panel Survey (Blanchflower, 1999; Hildreth, 1999; Swaffield, 2001; Machin, 2001). As noted earlier, and as both Lewis (1986) and Freeman (1984) pointed out, these estimates tend to be below the estimates obtained by OLS because of a downward bias induced by measurement error in the classification of union status. As also noted earlier, OLS estimates may be upwardly biased if unobserved heterogeneity accounts for some of wage variation attributed to union membership. Thus, for example, in Blanchflower (1999) the OLS estimate for the years 1991-93 was 10.6 per cent compared with 3.7 per cent when a full set of people fixed effects were included. ${ }^{7}$ As Freeman (1984, p. 24) has suggested, it may well be that the cross-section and fixed effect or "panel" estimates of the impact of unions on wages 'bound the true impact of unionism'.

Studies using individual pay data covering the first half of the 1990s also suggested that, while the union effect was persisting, the premium declined for some workers (Blanchflower, 
1999; Hildreth, 1999). For example, Hildreth (1999, p. 7) argues that stability in the union premium for blue-collar male workers in 1991-95 compared with a declining premium for their white-collar counterparts may reflect their respective abilities to maintain their bargaining power. The picture emerging from research through to 1998/99 is suggestive of a more widespread decline in the premium. Machin's (2001) analysis of longitudinal data from the British Household Panel Survey indicates that, although there was a wage gain for people moving into union jobs in the early 1990s, this had disappeared by the late 1990s. Booth and Bryan (2001) using linked employer-employee data for 1998 also found no significant wage premium. Bryson (2002) finds a membership premium for covered workers, but it is much smaller than the 10 per cent common in the literature. Furthermore, the premium is confined to employees in older workplaces and those with high union density. Forth and Millward (2000a) find the premium was confined to workers in workplaces with high bargaining coverage or multiple unions.

It would be hasty to assert, on the basis of this evidence alone, that unions' ability to secure better than market rates for their workers has declined since the 1980s because methodological and data differences across studies make comparisons extremely difficult (Andrews et al., 1998). It is even more difficult to establish what has happened to the trend over time. As Lanot and Walker (1998, p. 343) note: 'the existing literature says little about how the differential has changed over time there are so few studies it is difficult to take a view of whether there is any systematic movement over time'. For instance, using standard regression techniques deployed in most studies, Booth and Bryan (2001, p. 12) identify a membership premium of roughly 10 per cent. Bryson reports a similar regression-adjusted premium for the private sector (2002, p. 25). However, in both cases, the authors lay emphasis on the results they obtain 
through the use of other techniques (instrumental variables in the case of Booth and Bryan and propensity score matching in Bryson's case).

The disaggregated pattern of results reported by Lewis (1986) for the US appear to be broadly repeated for the UK. The main exception is that the wage gap in the UK appears to be larger for females than it is for males (see Blanchflower, 1999; Main, 1996). We explore this issue in more detail below.

In what follows a series of estimates for the union wage gap since 1973 are presented. What is the size of the union wage gap in the UK and the US in the twenty-first century? How much has it changed in the years since 1980, which is the end-point for Lewis' 1986 study? How much do the estimates vary by gender, race and across the public and private sectors? How large is the wage gap in other countries? In the following three sections, micro-data on individuals are used to estimate log hourly earnings equations first for a group of seventeen countries and then for the US and the UK. In the case of the US and the UK data are available over time that allow us to examine the time series properties of the union wage premium. Clearly, one would wish to examine the extent to which unions are able to influence the total compensation package including fringe benefits. Unfortunately, relatively little is known about the extent to which unions are able to influence fringe benefits, primarily because of a lack of suitable data. Such literature as does exist - most of which is for the US - suggests that these effects are large (see Freeman and Medoff, 1984, for the US; and Renaud, 1998, for Canada). For Britain, Forth and Millward (2000a) find unions enhance pension and sick pay provision in similar circumstances to those where they affect pay. But our data files do not contain information that permit us to examine this issue over time. 
Before moving to estimating union wage gaps, it is appropriate to place these results in the wider context of the changes in the labour market experience of the two countries over the last couple of decades; specifically, in terms of unemployment and employment; wage inequality, real wage growth and union density. This allows for some appreciation of the climate in which unions have been operating.

1. Unemployment was generally higher in the US than it was in the UK from 1965 to 1980 . The picture reversed itself in the later period, 1980-99. In 2000 and 2001 the unemployment rate in the UK was below that of the United States, averaging 3.4 per cent and 4.4 per cent, respectively (see Appendix Table 1). Both employment and the size of the labour force increased rapidly over the period 1990-2000 in the US. Over this period, employment in the US increased by 14 per cent while the labour force increased by 12 per cent ${ }^{8}$. The UK experienced smaller growth along both of these dimensions, with respective growth rates of 7 per cent and 3 per cent ${ }^{9}$.

2. Levels of earnings and wage inequality are high in the US and the UK compared with most other countries, and especially so in comparison with most European countries (Blanchflower, 2000). There was substantial growth in earnings inequality in the 1970s and 1980s in the US. Since the early 1970s earnings in the US have become much more unequal between more-skilled and less-skilled workers as well as between workers with high and low levels of education and those with many years of labour market experience compared to those with few. For example, in 1979 male college-educated workers earned on average 30 per cent more than male high-schooleducated workers. By 1995 this premium for college-educated workers had risen to about 70 per cent (Blanchflower, 2000). Earnings inequality declined in the UK in the 1970s but increased in the 1980s. Only Britain and the United States have continued to experience a rapid rise in inequality into the $1990 \mathrm{~s}$, albeit at a slower rate than had occurred in the $1980 \mathrm{~s}$. There is much 
less evidence of rising wage inequality in other countries (see the various papers in Freeman and Katz, 1995). Blanchflower (2000), for example, found that from 1973-1994/95 at the lower part of the distribution, the earnings of the median worker rose a lot in comparison to the worker at the first decile only in the UK and the US from a group of fifteen countries (Australia, Austria, Belgium, Canada, Finland, France, Germany, Italy, Japan, the Netherlands, New Zealand, Norway, Sweden, the UK and the US). Appendix Table 2 presents four measures of inequality for most of these countries at various points in time, using data from the Luxembourg Income Study. The measures reported are the Gini coefficient as well as the 90/10, 80/20 and 90/50 differentials. The table confirms the high levels of inequality in the US and the UK compared to other countries.

3. In the United States real wage growth has been much greater at the top of the earnings distribution than at the bottom. In the hundred years to 1973 , real average hourly earnings rose by 1.9 per cent a year. Between 1973 and 1997, CPI-deflated real wages have fallen by about 0.4 per cent a year. The combination of flat average wages and rising inequality means that large numbers of American workers have experienced stagnation or even absolute declines in their real earnings in recent decades. And workers at the low end of the earnings distribution have suffered the most, particularly those in the lowest decile. For example, the real hourly earnings of high-school-educated males fell by 20 per cent from 1979 to $1993 .^{10}$ In contrast, there has been considerable growth in real earnings at the top of the earnings distribution. Senior managers and executives have experienced large increases in real earnings over the last couple of decades, and especially so when total compensation including stock options are included.

In contrast to the United States, in most OECD countries (including the UK) there has been strong real earnings growth across the wage distribution. For only one or two countries 
(New Zealand and Australia) has a rise in earnings inequality implied weak growth or even declining real wages for workers at the bottom half of the earnings distribution ${ }^{11}$. The low-paid in most industrial countries have experienced real earnings growth over the last two decades ${ }^{12}$. In a comparison of seven OECD countries (Australia, Canada, France, the Netherlands, Sweden, the UK and the US), using data from the Luxembourg Income Study for the 1980s, Gottschalk (1993) shows that only in the US did the inequality of family income rise more than the inequality of earnings. In these countries, government actions through social expenditures mitigated somewhat the impact of increasing wage inequality.

4. Union density rates declined steadily in the US from $1970^{13}$. In Britain density increased in the 1970s and then declined dramatically. Appendix Table 1 provides the background data. Since 1991, there has been a decrease in union membership of 1.3 million, a fall over the ten-year period of 15 per cent. The fall in union membership has been steeper for men than for women over the past decade: union density for men was 42 per cent in 1991 and 29 per cent in 2001, whereas that for women was 32 per cent in 1991 and 28 per cent in 2001. There has been an even more pronounced decline in unionisation in Australia, where union density was 45.6 per cent in 1986 but only 28.1 per cent in 1998. Moreover, Australian union density continues to fall, with the latest estimate being 24.5 per cent ${ }^{14}$. The decline in density has also been pronounced in Japan and Austria. Some countries, including Denmark, Finland and Sweden, actually experienced increases in density over the period. (For a discussion, see Blanchflower and Freeman, 1992; Blanchflower, 1996; Ebbinghaus and Visser, 1999, 2000.)

Section 3 sets the scene by presenting evidence on the size of union wage premia in seventeen countries. In section 4 we make use of data from the Current Population Survey (CPS) to obtain estimates of the impact of trade unions on hourly earnings for the US. In section 
5 data from the UK Labour Force and British Social Attitudes Surveys are used for direct comparison with the US experience. Section 6 discusses the cyclical nature of the wage gap in the US and UK, and Section 7 presents our conclusions.

\section{Union wage differentials around the world}

Over the past couple of decades there has been a growing body of literature estimating the size of the union wage gap outside the UK and the US. There are a number of studies for Canada which suggest that the union wage gap is in the 10-15 per cent range (Doiron and Riddell, 1994; Robinson and Tomes, 1984; MacDonald and Evans, 1981; Lemieux, 1998; Kuhn and Sweetman, 1998, 1999; Donald, Green and Parsch, 2000; DiNardo and Lemieux, 1997). This estimate appears to have remained fairly constant over time ${ }^{15}$. Renaud (1998) provided the first empirical evidence of the impact of unions on benefits and total compensation in Canada using micro data from the Canadian General Social Survey (GSS) of 1989. His results suggest that the Canadian unions increased total compensation by 12.4 per cent, compared to an impact of 10.4 per cent on wages. Even though the union impact on total compensation is 2 per cent greater than the impact on wages, given that benefits comprise only about 6 per cent of total compensation in this sample, the percentage impact of unions on benefits is estimated to be 45.5 per cent. This latter estimate implies a very substantial impact of unions on benefits in Canada, as large or larger than estimates for the US.

In Australia the range is generally estimated to be between 7 and 17 per cent, with most estimates at the lower end of the range ${ }^{16}$. Blanchflower and Machin (1996) provide estimates of union wage premia for Australia using the 1989/90 Australian Workplace Industrial Relations Survey (AWIRS90) where the establishment is the unit of observation. They found significant wage differentials for labourers and unskilled workers of 15.6 per cent but no evidence of 
significant differentials in respect of plant and machine operators, sales and personal service workers, clerks, tradespersons, para-professionals or professionals - along with evidence of a negative differential for managers. More recently, Miller and Mulvey (1996) have reported evidence that union premia in Australia are small. Using individual level data from the 1993 Survey of Training and Education, they calculate the union wage effect to be 2.6 per cent for men and 1.6 per cent for women. Wooden $(2001$, p. 2) takes exception to this result and argues that previous research has understated the impact of unions 'by focusing on differences across individuals rather than differences across bargaining units'. Using data on 11,840 individual workers from 1,357 workplaces in the 1995 Australian Workplace Industrial Relations Survey (AWIRS95), Wooden showed that simply including a union membership dummy produces insignificant differentials for both men and women ${ }^{17}$. However, Wooden found that at those workplaces where the majority of workers were covered by collective agreements a strong union presence conferred a wage advantage of the order of 15 to 17 per cent to members and nonmembers alike relative to workers in workplaces where collective agreements had not been negotiated and where union wage effects were found to be small and insignificant. This does seem to make some sense because in Australia union negotiated agreements and awards typically apply to both members and non-members within the same workplace, and in the case of awards to all workers within the same industry. Further, Wooden and Bora (1998) use the AWIRS95 data file and find that the wage premium associated with union membership in unionised workplaces (compared with non-union workplaces) is as high as 7.7 per cent. They found this was only the case where (a) all workers at the workplace were union members and (b) where the union was relatively 'active'. (An 'active union' is defined as one in which the senior delegate from the union with most members spends one hour or more each week on union activities, and 
where a general meeting of members is held at least once every six months or delegates meet regularly with management.)

Moll (1993) estimated the 1985 union premium in South Africa at 24 per cent for black blue-collar workers (19 per cent for black males and 31 per cent for black females) and 13 per cent for whites. Schultz and Mwabu (1998) found that among male African workers in the bottom decile of the wage distribution, union membership was associated with wages that were 145 per cent higher than those of comparable non-union workers; among those in the top decile, the differential was 19 per cent. For South Korea, Park (1991) obtained estimates of 4.2 per cent for men and 5 per cent for women. Wagner (1991) found significant positive union effects for blue-collar workers in Germany, while Schmidt (1995) found small but significant wage differentials of less than 6 per cent. Neither Schmidt (1995) nor Schmidt and Zimmermann (1991) were able to find evidence of significant union wage gaps in Germany for male workers.

(Table 1 near here)

In Table 1 we estimate union wage gaps for seventeen countries from three continents Australia, Austria, Brazil, Canada, Chile, Cyprus, Denmark, France, Germany, Italy, Japan, the Netherlands, New Zealand, Norway, Portugal, Spain and Sweden ${ }^{18}$. The data used are from the 1994-99 International Social Survey Program (ISSP) ${ }^{19}$. The dependent variable is the log of earnings/wages/income with the exact measure used being variously defined across countries but consistent over time. Included in each equation is a restricted set of controls: age, age squared, years of schooling, private sector, and union status. The samples are restricted to employees only. The small number of controls will imply that the estimated union effects reported here are biased. Given that the same controls are used in each country in each year, our best hope is that such biases are constant over space and time. The quality and size of the data files are not 
comparable to those we use below for the US and the UK, and for that reason the reader is warned be cautious in interpreting these cross-country results. The (unweighted) average differential across these countries is 12.1 per cent.

Countries appear to fall into three groups. The first group of just two countries has a wage differential in excess of 20 per cent, namely, Brazil (40 per cent) and Japan (29 per cent). The second group of ten countries have more modest, but still material, differentials of around 10 per cent - Australia (13 per cent), Austria (16 per cent), Canada ( 9 per cent), Chile (17 per cent), Cyprus (15 per cent), Denmark (17 per cent), New Zealand (10 per cent), Norway (8 per cent), Portugal (20 per cent) and Spain (7 per cent). Trade unions in the final group of five countries have no measured impact on the wage - France, Germany, Italy, the Netherlands and Sweden. In these countries, the union wage gap is zero primarily due to the fact that unions are also able to control wage outcomes in the non-union sector.

(Table 2)

Panels (a) and (b) of Table 2, which report union density rates for these countries and chart how they have changed over time, suggest a helpful way of classifying the observed differences in wage premia.

1. Two countries with dramatic declines in density - Austria and Japan - have estimated differentials in double digits. (Below we shall show the UK and the US are similar.) In the case of Austria, it seems that a big increase in inequality accompanied this decline in unionisation (see Appendix Table 2). Australia and New Zealand have declining density and a positive union wage differential, although it should be noted that the decline in unionisation in New Zealand is a very recent phenomenon (see Maloney and Savage, 1996; Maloney, 1998). Portugal also has declining unionisation rates and a sizeable wage gap (see Blanchflower, 2001). 
2. The distinguishing feature of the group of countries that have union wage premia of zeroGermany, Italy, the Netherlands and Sweden - is high levels of union coverage, and unions' ability to influence wage setting in the non-union sector by extension of collectively bargained rates. (France is an exception in that it has very low union membership rates but approximately 100 per cent coverage.) It is also clear from Appendix Table 2 that, with the exception of Italy, income inequality is low in these countries.

3. Four countries with significant differentials - Canada, Denmark, Norway and Spain - have all had constant or rising levels of union density over the last few decades ${ }^{20}$.

4. Little is known about the labour market in Cyprus or Chile. According to our ISSP files, union density averaged 62 per cent and 10 per cent, respectively, in the two countries over the sample years.

5. The large estimate for Brazil is based on a single year of data with few controls and less than 1,000 observations and should be interpreted with caution.

We now turn to an examination of union wage premia in the US and the UK, for which countries we have better quality data and more data points. The data will also permit us to examine movements in differentials over time.

\section{Union wage differentials for the United States}

Table 3 presents estimates of the wage gap using separate log hourly earnings equations for each of the years from 1973 to 1981 using the National Bureau of Economic Research's (NBER) May Earnings Supplements to the Current Population Survey (CPS $)^{21}$ and for the years since then using data from the NBER's Matched Outgoing Rotation Group (MORG) files of the CPS $^{22}$. The MORG data for the years 1983-1995 were previously used in Blanchflower (1999) ${ }^{23}$. For both the May and the MORG files a broadly similar, but not identical, list of control variables is 
used, including a union status dummy, age and its square, a gender dummy, education, race and hours controls plus state and industry dummies ${ }^{24}$.

(Table 3 near here)

The first and third columns of Table 3 report the union coefficient in log hourly earnings equations for the total sample and the private sector, respectively. Hirsch and Schumacher (2002) have recently shown that there is what they call a 'match bias' in union wage gap estimates due to earnings imputations ${ }^{25}$. They show that this bias arises because currently 30 per cent of workers in the Current Population Survey have earnings imputed using a "cell hot deck" method. This means that wage gap estimates are biased downward when the attribute being studied (e.g. union status) is not a criterion used in the imputation. They show that standard union wage gap estimates such as reported in Blanchflower (1999) are understated by about 3 to 5 percentage points as a result of including individuals who have had their earnings imputed. By construction, then, the individuals with imputed earnings have a union wage gap of zero; hence omitting them raises the size of the union wage gap. Unfortunately, it is not a simple matter to exclude those individuals with imputed earnings in a consistent way over time ${ }^{26}$. Here we follow the procedure suggested by Hirsch and Schumacher (2002). All allocated earners are identified and excluded for the years 1983-88 and 1996-2001 in the MORG files. For 1989-95, allocation flags are either unreliable (in 1989-93) or not available (1994 through August 1995). For 198993, the gaps are adjusted upward by the average imputation bias during 1983-88. For 1994-95, the gap is adjusted upward by the bias during 1996-98. Because the May CPS sample files available to us do not include allocated earnings in 1973-81, the series are adjusted upward by the average bias (of .033) found by Hirsch and Schumacher using these May CPS data for 197981. Time-consistent estimates of union wage gaps, with match bias removed, are presented for 
1973-2001 in the second and fourth columns of Table 3 for the economy as a whole and for the private sector, respectively. These estimates are larger than those reported in the first and third columns of the table, which included individuals with imputed earnings ${ }^{27}$. In each year there are approximately 160,000 observations for the US economy and 130,000 for the private sector in the MORG; in the May files, sample sizes are approximately 38,000 and 31,000 respectively until 1980 and 1981 when sample sizes fall to approximately 16,000 and 13,000, respectively, as from that date on only respondents in months four and eight in the outgoing rotation groups report a wage.

\section{(Table 4 near here)}

Table 4 reports the estimated wage gaps derived by taking the antilogs of the coefficients in (the second and fourth columns of) Table 3 and deducting one. Separate results are reported for the economy as a whole as well as the private sector. Results obtained by Hirsch and Schumacher (2002) are also reported in the final column of the table. A number of facts emerge: 1. On average the wage differential over the period is approximately 18 per cent. This compares with an average of just over 14 per cent when similar calculations are performed using the first and third columns of Table 3 which include workers with imputed wages ${ }^{28}$.

2. The size of the union wage gap or mark-up is the same in the private sector as it is in the economy as a whole.

3. There appears to be a decline in the size of the differential since 1995, as the US economy entered a boom period. We later examine this issue in more detail as we find similar results in the UK.

4. The private sector differentials we report in the second column of Table 4 are smaller than those obtained by Hirsch and Schumacher (2002) in the third column of the table. Why? It 
appears the answer is because of the sensitivity of the union coefficient to changes in the controls. We illustrate this by pooling the MORG files, excluding those with imputed earnings data, for the six years 1996-2001 for the public and private sectors combined. The union coefficient changes as follows as controls are added:

CPS MORG: 1996-2001 $(\mathrm{n}=663,564)$

1. No controls except time

2. + age, age $^{2}+$ male .203

3. + race $(4)$

4. + education (15)

.191

5. + usual hours

6. + organisational status (4)

7. + state dummies (50)

8. + industry dummies (50)

9. +8 1-digit occupation dummies

10. replace 8 occupation dummies with 85 2-digit occupation dummies

11. Hirsch/Schumacher specification (Age, age $^{2}$, male, race (4), education (15), .199 marital status (6), occupation (8), industry (9), region (8))

Only including time as a control $(1996=0,1997=1, \ldots$, etc.) produces a coefficient of .321 . Progressively adding controls that are correlated with union status reduces the coefficient to .145 in line 8 , which is the specification we use in Tables 3 and 4 . In row 11 we report the specification used by Hirsch and Schumacher (2000), which includes many fewer controls than used in our preferred specification in line 8. There is a large literature supporting the inclusion of controls for local labour market characteristics (e.g. Blanchflower and Oswald, 1994) and industry characteristics (e.g. Blanchflower, Oswald and Sanfey, 1998). Adding occupation dummies, especially at the two-digit level, appears to raise the size of the differential by approximately 4 percentage points, confirming the point made by Hirsch and Schumacher $(1998)^{29}$. Our view is that it is not appropriate to include occupation controls here as they are likely nothing more than slices (deciles/percentiles?) of the wage distribution itself. In private 
correspondence, Barry Hirsch has disagreed with this view and argued that occupation dummies should be included because they reflect large differences in skill not controlled for by years of schooling and age. Given that there is a large variation in individual union status within broad occupation groups, his view is that they may be an appropriate control. There is no simple way to resolve this issue - it is a substantive point that does influence the level of the differential although it appears to have little effect on the time-series properties of the differential. We have simply agreed to disagree on this one and let the reader decide. As ever, the truth probably lies somewhere in between!

The results reported in Table 4 are broadly comparable to the estimates obtained by $\mathrm{H}$. Gregg Lewis (1986) in his Table 9.7, which summarised the findings of 165 studies for the period 1967-79. Lewis concluded that during this period the US mean wage gap was approximately 15 per cent. His results are reported below ${ }^{30}$ :

$\begin{array}{lrrrrc}\text { Year } & \text { \# studies } & \text { mean estimate } & \text { Year } & \text { \# studies } & \text { mean estimate } \\ 1967 & 20 & 14 \% & 1973 & 24 & 15 \% \\ 1968 & 4 & 15 \% & 1974 & 7 & 15 \% \\ 1969 & 20 & 13 \% & 1975 & 11 & 17 \% \\ 1970 & 8 & 13 \% & 1976 & 7 & 16 \% \\ 1971 & 20 & 14 \% & 1977 & 10 & 19 \% \\ 1972 & 7 & 14 \% & 1978 & 7 & 17 \% \\ & & & 1979 & 3 & 13 \%\end{array}$

The left panel contains estimates for the six years prior to our starting point in Table 4. It does appear that the unweighted average for this first period, 1967-72, of 14 per cent is slightly below that of the second interval, 1973-79. The estimates for the later period are in turn somewhat smaller than those we obtained in Table 4 - which averaged 20 per cent - but appear to have the same time-series pattern; for example, 1979 has the lowest value in both sources. In part, the low number Lewis obtained for 1979 is explained by the fact that the 1979 May CPS file 
included allocated earners and hence the estimates were not adjusted for the downward bias caused by the imputation of the earnings data ${ }^{31}$.

(Table 5 near here)

Table 5 uses the same pooled MORG file as we used above to examine the sensitivity of the union coefficient to changes in controls for the years 1996-2001, but this time to measure disaggregated union wage gaps. The first row entry of column 1 presents the union coefficient of .145 obtained from specification 8 above, which included a full set of controls except occupation. The coefficient is exponentiated in column 4 giving an overall differential of 15.6 per cent. Reading down that column, estimates for males and females and the public and private sectors are broadly the same $\mathrm{s}^{32}$, and union wage effects are higher for the young and the least educated, non-whites, part-timers, manual workers, and non-manufacturing. These results are similar to those found by Lewis (1986), who concluded that the gap was greater for blacks than whites; in services than in manufacturing; for construction than for other non-manufacturing; for blue-collar workers than for white-collar; and for private- than for public-sector workers. As do we, Lewis concluded that the estimates for men and women were approximately the same. Further, Lewis found that the wage gap fell as years of schooling, establishment or firm size and industry unemployment rates rose. For age, years of experience and years of seniority the gap at first fell and then increased. The robustness of Lewis's results were broadly confirmed by Jarrell and Stanley (1990) using meta-analysis, although their mean estimate of the wage gap for the period was a little lower than that obtained by Lewis. There is very little new under the sun!

Columns 2 and 3 of Table 5 report the results of including both a union variable and a union*time interaction term. In all cases, the interaction term is negative and significant, implying for all groups a significant decline in the size of the premium between 1996 and 2001. 
The penultimate two columns attempt to enumerate the scale of these declines. In the fifth column headed 'Wage gap 1996' the union*time term is set to zero and the union coefficient is exponentiated (i.e. for row 1 antilog $(.167-[.012 * 0]$ minus $1=18.2 \%)$ ). In the next column the same exercise is performed for the end year of 2001 when time $=5$. Hence, in this case the calculation is (i.e. for row 1 antilog (.167-[.012*5] minus $1=11.3 \%)$, implying an overall decline of just under 7 percentage points in the differential between 1996 and 2001. The decline has been greatest over the period among the most highly educated and in services (see the summary results in the final column of the table). But all groups have experienced a substantial decline in the wage premium. In 1996, the premium was above $15 \%$ for all but 3 of the 17 worker types. In 2001, it was below $15 \%$ for all but 3 of the worker types.

Is the relatively high differential in the US an artifact of sample selectivity? In Blanchflower and Freeman (1992) it was argued that this is not the correct way to interpret the data and this is still our view. The reasons given, which are still relevant, were as follows:

1. Evidence within the US tends to reject the notion that union wage effects are large when union density is small. Union wage differentials tend to be greater, the greater the extent of unionisation in the sector (see Lewis, 1986; Freeman and Medoff, 1984), presumably because this gives unions greater bargaining power.

2. If selectivity were the major cause of the estimated large effects of unionism on wages in the US, similar differences in other labour market outcomes should be expected, which is not the case.

3. Third, the fact that employers as well as workers affect union density makes the direction of the selectivity effect uncertain (Farber, 2001). One might well argue that selectivity operates to 
bias downward union wage effects as employers fight hardest against unions that have the most potential for raising wages and accept unions when they have the least potential.

4. Massive employer opposition to unions in the US, but not elsewhere, is consistent with the union demand for higher wages being greater in the US than in other countries.

All of this does not deny the possibility that our estimates may be contaminated by the reverse effects of density on wage differentials. But any such potential contamination is unlikely to reverse the finding that union wage differentials are relatively high for similar workers in the US relative to other countries.

An obvious question to ask is: why has union membership and union employment been in decline given the relative constancy of the union wage premium in the years up to 1995? The level of the differential - at around 18 per cent - is still very high by international standards. The United States decides union membership through an adversarial electoral process at plant level, which has evolved into a system where management has a greater say in unionisation outcomes than it does in other countries. The benefit to employers in removing unions from the workplace often outweighs the costs of doing so. The costs to unions in organising recruitment drives is high: Farber and Western (2001) estimate that in order to match the rate of union organising seen in the 1970s unions would have to organise 374,000 private sector employees a year, which is much more than is currently being achieved $(99,000)$. Their lower-bound estimate of the cost of doing so is $\$ 575.5$ million per year, or about $\$ 64$ per union member ${ }^{33}$. Bender (1997) has further argued that the loss of economies of scale in union organising is an important factor in explaining union decline. It is much harder for employers in other countries to get rid of unions than it is in the US. Even in the UK there are only a very few examples of union de-recognition (Millward, Bryson and Forth, 2000). Employers are unable to hide from a union; they have no 
place to go. The decline in US unionism seems to have been driven by employer opposition, fueled by more competitive product markets, increased international trade and a favourable legal environment, as a result of which there have been smaller economic rents to be shared with workers than was true in the past ${ }^{34}$. Linneman, Wachter and Carter $(1990$, p. 51) have gone even further and suggested that the evidence of a relatively constant aggregate union wage premium is a 'statistical artifact'. High premium industries, they show, have been increasing their union wage premia and losing employment shares and hence membership of trade unions. Union wage premia in private services, they argue, have held constant or fallen. They argue that even though unions have been hurt by exogenous factors, which have created shifts in demand from goods to service-producing industries, they have been hurt most by the rising wage premia. Supporting evidence for this view is presented by Freeman (1986), who found a positive correlation between the union wage gap and a proxy for managerial opposition to unions, namely, the number of unfair labor practices per worker in NLRB elections. Farber (1990) also concludes that the decline was principally a result of increased employer opposition to unions along with lower demand for union services by workers.

The results in this chapter suggest that the union wage differential in the US is comparatively high, although there is now some, admittedly weak, evidence of countries with even larger effects (see above). However, it is unclear how much weight should be placed on the latter estimates, which are based on small sample sizes. The decline in union density in the US does not appear to be an aberration but is structurally rooted in what unions do on the wage front. Whereas in the 1950s and 1960s the large differentials that US unions gained were probably economically justified given the United States' role as world economic leader, the increased 
differentials that emerged in the 1970s still appear to be a major liability to the future development of unionism in the US.

\section{Union wage differentials for the United Kingdom}

Evidence to date is merely suggestive of a declining union wage premium: there are few studies estimating the union wage premium with consistent time-series data, and recent studies use techniques which were not used in earlier analyses ${ }^{35}$. This gap in the evidence is filled by analyses of the union wage premium over the period 1985-2001 presented in Table 6. We use two data sources: the Labour Force Survey (LFS) for the UK, and the British Social Attitudes Surveys (BSAS). The LFS estimates tend to be above the BSAS estimates, but in both series there has been a decline in the log hourly union wage premium since 1994 (with the BSAS estimate for 1997 being an outlier, perhaps due to the much smaller sample that year). ${ }^{36}$ Although the premium remains roughly 10 per cent in the 2000 LFS, it falls to a statistically insignificant 5 per cent in BSAS 2000, and falls even further in 2001. Both series are based on standard specifications for each separate year (detailed in the notes to Table 6). In identifying the union effect over time, we make what we think is the reasonable assumption that any bias in our estimates arising through unobserved heterogeneity is constant over time.

(Tables 6 and 7 near here)

Table 7 presents log hourly wage estimates for the United Kingdom based on pooled years from the $\mathrm{LFS}^{37}$. It adopts the same format and methodology as the CPS estimates presented in Table 5. The purpose is to show the variation in the membership premium across types of worker, and how the downward trend in the premium since the mid-1990s has affected each group. The fourth column of row 1 shows that, for the period 1993-2000, the hourly union wage premium across the economy was 9.9 per cent $(n=105,112)$. This figure is the 
exponentiated coefficient based on the point estimate of .094 in the first column. This point estimate for the union coefficient changes as follows as controls are added:

UK - LFS files: 1993-2000 ( $\mathrm{n}=105,000)$

1. No controls except time

2. +age, age $^{2}+$ male

3. + race .185

4. + education .118

5. + workplace size .074

6. + region dummies .097

7. + industry dummies .094

8. +1 digit occupation dummies

9. +2 digit occupation dummies .104

The coefficient falls with the addition of new controls, particularly at stages 2 and then at stage 5 when workplace size is introduced. However, it rises a little in stages 6 and 7, pointing to the fact that unobserved heterogeneity can both upwardly and downwardly bias estimates of the union wage premium. As was found above for the US, the addition of 1- or 2-digit occupation dummies increases the size of the estimated union effect. However, in contrast to the US, the size of the union effect does not rise as we move from 1-digit to 2-digit occupation dummies.

Returning to Table 7, the entries in the fourth column show that the union premium is highest among manual workers, part-timers, and women. These are all groups with traditionally low earnings. Conversely, the premium is lowest among the traditionally higher paid, namely, men and the highly educated. In the same way as described for the US data in Table 5, the fifth and sixth columns of Table 7 use the information generated by a union*time interaction - the data are reported in columns 2 and 3 - to show the premium in 1993 and 2000 for the whole economy and for seventeen sub-groups of employees. In the whole sample, the wage gap dropped from 14.2 per cent in 1993 to 6.3 per cent in 2000 . What is remarkable is the evidence of a large fall in the wage premium across most types of worker, indicated by the sub-group 
regressions. In 1993 only one group of employees (the highly educated) had a premium well below 10 per cent. In 2000, all but three out of the 17 types of worker had a premium below 10 per cent. Those worse affected were manufacturing workers, men, private sector workers and non-whites, all of whom had no significant premium by 2000 .

\section{(Table 8 near here)}

Table 8 performs a similar task to Table 7, this time presenting differences in the union wage premium for Britain, but based on pooled years from the BSAS 1985-2001 ${ }^{38}$. The first column shows that, for the period 1985-2001, the hourly union wage premium across the economy was around 9 per cent. This point estimate for the union coefficient changes as follows as controls are added:

BSAS files: 1985-2001 $(\mathrm{n}=17,934)$

1. No controls except categorical time dummies

2. +5 age dummies + female

3. +7 education dummies

4. + full-time status + manual

.111

5. +6 workplace size dummies

6. +6 region dummies

.082

7. + manufacturing dummy

The coefficient falls with the addition of new controls from stages 1 to 3 , rises a little when full-time and manual status are controlled for, then falls substantially with the workplace size dummies, as happened with LFS. Again, as with the LFS, the coefficient rises with region and industry dummies. The sub-group analysis in the first column of Table 8 shows that, over the whole period, the wage premium was highest among manual workers, part-timers, those with low or no qualifications and women, again reflecting the LFS findings.

The simplest way to show the impact of the declining union premium across types of worker in BSAS is to estimate the premium for each group before the decline occurred (1993- 
95), and then again at the end of the period (1999-2001). These estimates are presented in the last two columns of Table 8. In 1993-95, only two types of worker (non-manuals and the highly qualified) had a union premium of less than 10 per cent. By 1999-2001, eleven types of worker had a premium of less than 10 per cent. For five types of worker (men, younger workers, those in the private sector, non-manuals, and the highly educated) the membership premium was no longer statistically significant.

Across the economy as a whole, the membership premium fell from 12.2 per cent in 1993-95 to 5.1 per cent in 1999-2001. What is interesting is the way that the premium collapses for some workers. For instance, there has always been a ranking in the premium according to educational attainment, with membership raising the wages of the least qualified most. This is apparent in the second column for the period 1993-95. But what is striking is that, by 19992001, the premium for the highly qualified is flattened. Similarly, full-timers saw their premium plummet to a barely statistically significant $(\mathrm{t}=1.97) 3.3$ per cent, while the premium held up well for part-timers. The premium has also held up well in the public sector, among older workers, and among manual workers, but it has all but collapsed in the private sector, among younger workers, and among non-manuals.

The case of male workers is unique. The table shows that, whereas the premium was similar for men and women in the mid-1990s, it was considerably lower for men than for women by the end of the period. However, the picture changes on introducing a public sector control. As note $\mathrm{c}$ to the table points out, the public sector dummy was omitted from the results presented because it was not available for the 1994 and 1995 surveys. However, we reran all estimates including the public sector dummy for years where the public sector dummy was available to check the sensitivity of our results. Calculating the premia for men and women for 1993 only 
produces results similar to the $1993-95$ pooled estimates but, with the public sector added to the pooled 1999-2001 analysis the male union premium is estimated to be 6.3 per cent, while that for women is 5.7 per cent. Thus, once the public sector control is included, men's and women's membership premium is not significantly different in the later period. This is because the public sector dummy is negative and significant in the case of men, but non-significant in the case of women. The explanation is straightforward. Because public sector employment and unionisation are highly correlated, in the absence of a public sector control the union membership dummy is picking up the negative wage differential of public sector workers among men. For women, the addition of the public sector control makes no difference because there is no negative public sector wage differential among women.

\section{The cyclical nature of the wage gap in the United States and the United Kingdom}

Figure 1a plots the point estimates of the union wage premium for the US, taken from the first column of Table 4, against unemployment for 1973-2000. Figure 1b does the same for Britain for 1985-2001, using the data from the last column in Table 6. In both countries the premium is counter-cyclical. Regressions were then run for each of the countries with the union premium as the dependent variable - using the data from Table 4 for the US and Table 6 for the UK (when there were observations in a single year from both the LFS and the BSAS, the average of the two was used) for the years 1973-2001. Each equation included a highly significant, and positive, US dummy. The one year lag on the unemployment rate was significantly positive ( $\mathrm{t}$ statistics are in parentheses) whether a lagged dependent variable was excluded (equation 5) or included (equation 6). The level of unemployment was never significant and is excluded in the 
equations below. The time trend is also not significant. When the time trend was replaced by the union density rate that was also insignificant and the other results were the same:

$$
\begin{aligned}
& \text { Premium }_{\mathrm{t}}=6.026+.700 \text { Unemployment }_{\mathrm{t}-1}-.055 \text { time }+8.387 \mathrm{US} \\
& \text { (2.54) (3.10) } \\
& \left(\mathrm{N}=42, \mathrm{R}^{2}=.769\right) \\
& \text { Premium }_{\mathrm{t}}=5.452+.248 \text { Premium }_{\mathrm{t}-1}+.511 \text { Unemployment }_{\mathrm{t}-1}-.079 \text { time }+6.108 \mathrm{US} \\
& \text { (2.40) (2.24) } \\
& \left(\mathrm{N}=42, \mathrm{R}^{2}=.797\right)
\end{aligned}
$$

These regressions support the notion that the union wage premium is counter-cyclical, moving positively with changes in the (lagged) unemployment rate. Thus, as unemployment falls, as it has done since 1995, the union wage premium falls; and as unemployment rises the wage premium rises. As the economy moves into boom the differential falls, and as it moves into recession the premium rises: unions are better for workers in slumps than they are in booms. Further, the insignificance of the time trend implies the premium is untrended. So, contrary to what some commentators, particularly British ones, have been suggesting, it seems the recent decline in the union wage premium is not necessarily a secular decline, but a decline induced by favourable labour market conditions. What this suggests is that, when demand for labour is strong, employees are less reliant on unions to bargain for better wages because market wages rise anyway. However, when market conditions are less favourable to workers, the premium rises because union bargaining cushions members from market fluctuations. So, although there are indications that the benefits of membership - as measured by the wage premium - have declined since the mid-1990s, this may be a cyclical phenomenon. The premium may rise again in the face of deteriorating economic conditions currently being experienced at the time of writing (October 2002). Furthermore, although it is possible that a decline in the net benefits of membership has induced a decline in union density, trends in the wage premium can only help 
explain falling density since the mid-1990s, since the premium was fairly stable before that point. In the years up to 1995 this could be a batting average effect. As union density declines, the more powerful unions are the ones that remain. The weaker batsmen are removed from the batting order so the team's average rises. Another possibility, of course, is that a high union/nonunion wage differential provides an incentive for employers to try and reduce union power. The fact that the differential remained more or less constant in both the UK and the US for so long is a puzzle, particularly given the rapid declines in union membership in both countries. The evidence is not consistent with the widely held view that union power has been emasculated.

\section{Conclusions}

This paper has attempted to address the question: 'what do unions do on the wage front?' The answer in the cases of both the US and the UK is that, despite declining membership numbers, unions are able to raise wages substantially over the equivalent non-union wage. Unions in other countries, such as Australia, Austria, Brazil, Canada, Chile, Cyprus, Denmark, Japan, New Zealand, Norway, Portugal and Spain, are also able to raise wages by significant amounts. In countries where union wage settlements frequently spill over into the non-union sector (e.g. France, Germany, Italy, the Netherlands and Sweden) there is, as one might expect, no significant union wage differential. The estimates from the seventeen countries we examined averages out at 12 per cent.

Time series evidence from both the US and the UK suggests three interesting findings. First, the union differential in the US is higher on average than that found in the UK (18 per cent compared with 10 per cent). Second, the union wage premium in both countries was untrended in the years up to the mid-1990s. Third, in both countries the wage premium has fallen in the boom years since 1994/95. It is too early to tell whether the onset of a downturn in 2002 will 
cause the differential to rise again or whether there is a trend change in the impact of unions. It is our view that most likely what has happened is that the tightening of the labour market has resulted in a temporary decline in the size of the union wage premium. Time will tell whether the current loosening of the labour market, that is occurring in both countries, will return the union wage premium to its long run values of 10 per cent in the case of the UK and 18 per cent in the case of the US. On the basis of past experience it seems likely that they will. 
Endnotes 


\section{References}

Andrews, M. J., D. N. F. Bell, and R. Upward (1998), 'Union Coverage Differentials: Some Estimates for Britain Using the New Earnings Survey Panel Dataset', Oxford Bulletin of Economics and Statistics, 60 (1), 47-78.

Andrews, M. J., M. B. Stewart, J. K. Swaffield, and R. Upward (1998), 'The Estimation of Union Wage Differentials and the Impact of Methodological Choices', Labour Economics, 5 (4), 449-474.

Bender, K. A. (1997), 'The Changing Determinants of U.S. Unionism: An Analysis Using Worker-Level Data', Journal of Labor Research, 18 (3), 403-423.

Blackaby, D. H., P. D. Murphy, and P. J. Sloane (1991), 'Union Membership, Collective Bargaining Coverage and the Trade Union Mark-Up for Britain', Economics Letters, 36 (2), 203208.

Blanchflower, D. G. (1984), 'Union Relative Wage Effects: A Cross-Section Analysis Using Establishment Data', British Journal of Industrial Relations, 22 (3), 311-332.

Blanchflower, D. G. (1986), 'What Effect Do Unions Have on Relative Wages in Great Britain?', British Journal of Industrial Relations, 24 (2), 196-204.

Blanchflower, D. G. (1991), 'Fear, Unemployment and Pay Flexibility', Economic Journal, 101 (406), 483-496.

Blanchflower, D. G. (1996), 'The Role and Influence of Trade Unions in the OECD', Report to the Bureau of International Labor Affairs, Washington, D.C.: U.S. Department of Labor, August.

Blanchflower, D. G. (1999), 'Changes Over Time In Union Relative Wage Effects in Great Britain and the United States', in S. Daniel, P. Arestis, and J. Grahl (eds.), The History and Practice of Economics: Essays in Honour of Bernard Corry and Maurice Peston, Volume. 2, Northampton, Mass.: Edward Elgar, pp. 3-32.

Blanchflower, D. G. (2000), 'Globalization and the Labor Market', Report to The Trade Deficit Review Commission, downloadable at http://www.ustdrc.gov.

Blanchflower, D. G. (2001), 'Unemployment, Well-Being and Wage Curves in Eastern and Central Europe', Journal of Japanese and International Economies, 15 (4), 364-402.

Blanchflower, D. G., and R. B. Freeman (1992), 'Unionism in the U.S. and Other Advanced OECD Countries', Industrial Relations, 31 (1), 156-179; reprinted in M. Bognanno and Morris M. Kleiner (eds.), Labor Market Institutions and the Future Role of Unions, Oxford: Blackwell, pp. 56-79. 
Blanchflower, D. G., and S. Machin (1996), 'Product Market Competition, Wages and Productivity: International Evidence from Establishment Level Data', Annales d'Economie et de Statistique, 41/42, 220-253.

Blanchflower, D. G., and A. J. Oswald (1994), The Wage Curve, Cambridge, Mass.: MIT Press.

Blanchflower, D. G., A. J. Oswald, and M. Garrett (1989), 'Insider Power and Wage Determination', Economica, 57 (226), 143-170.

Blanchflower, D. G., A. J. Oswald, and P. Sanfey (1996), 'Wages, Profits and Rent Sharing', Quarterly Journal of Economics, 111 (1), 227-251.

Booth, A. L., and M. L. Bryan (2001), 'The Union Membership Wage-Premium Puzzle: Is There A Free Rider Problem?', Working Paper, Institute for Social and Economic Research, University of Essex.

Brook, K. (2002), 'Trade Union Membership: An Analysis of Data from the Autumn 2001 LFS', Labour Market Trends, 110 (7), 343-354.

Brown, W., S. Deakin, M. Hudson, C. Pratten, and P. Ryan (1998), The Individualisation of Employment Contracts in Britain', Employment Relations Research Series 4, London: Department of Trade and Industry.

Bratsberg, B., and J. F. Ragan (2002), 'Changes in the Union Wage Premium by Industry - Data and Analysis', Industrial and Labor Relations Review, 56 (1) October [forthcoming]..

Bryson, A. (2001), 'Union Effects on Workplace Governance, 1983-1998', PSI Discussion Paper No. 8, London: Policy Studies Institute.

Bryson, A. (2002), 'The Union Membership Wage Premium: An Analysis Using Propensity Score Matching', Discussion Paper No. 530, Centre for Economic Performance, London School of Economics.

Budd, J.W., and I-G Na (2000), 'The Union Membership Wage Premium for Employees Covered by Collective Bargaining Agreements', Journal of Labor Economics, 18 (4), 783-807.

Card, D. (1996), 'The Effect of Unions on the Structure of Wages: A Longitudinal Analysis', Econometrica, 64 (4), 957-979.

Christie, V. (1992), 'Union Wage Effects and the Probability of Union Membership', Economic Record, 68 (200), 43-56.

Dinardo, J., and T. Lemieux (1997), 'Diverging Male Wage Inequality in the United States and Canada, 1981-1988: Do Institutions Explain the Difference?', Industrial and Labor Relations Review, 50 (4), 629-651. 
Doiron, D. J., and C. W. Riddell (1994), 'The Impact of Unionization on Male-Female Earnings Differences in Canada', Journal of Human Resources, 29 (2), 504-534.

Donald, S. G., D. A. Green, and H. J. Paarsch (2000), 'Differences in Wage Distributions between Canada and the United States: An Application of a Flexible Estimator of Distribution Functions in the Presence of Covariates', Review of Economic Studies, 67 (4), 609-633.

Ebbinghaus, B., and J. Visser (1999), 'When Institutions Matter. Union Growth and Decline in Western Europe, 1950-1995', European Sociological Review, 15 (2), 135-158.

Ebbinghaus, B. and J. Visser (2000), Trade Unions in Western Europe Since 1945, London: Macmillan.

Farber, H. S. (1990), The Decline of Unionization in the United States: What Can Be Learned from Recent Experience', Journal of Labor Economics, 8(1), Part 2, January, pp. S75-S105.

Farber, H. S. (2001), 'Notes on the Economics of Labor Unions', Working Paper 452, Princeton University Industrial Relations Section.

Farber, H. S. and B. Western (2001), 'Accounting for the Decline of Unions in the Private Sector, 1973-1998', Journal of Labor Research, 22 (3), 459-486.

Farber, H. S. and B. Western (2002), 'Ronald Reagan and the Politics of Declining Union Organization', British Journal of Industrial Relations [forthcoming].

Forth, J., and N. Millward (2000a), 'The Determinants of Pay Levels and Fringe Benefit Provision in Britain', NIESR Discussion Paper No.171, London: National Institute for Social and Economic Research.

Forth, J., and N. Millward (2000b), 'Pay Settlements in Britain', NIESR Discussion Paper No.173, London: National Institute for Social and Economic Research.

Forth, J., and N. Millward (2002), 'Union Effects on Pay Levels in Britain', Labour Economics, $9(4), 547-562$.

Freeman, R. B. (1984), 'Longitudinal Analyses of the Effects of Trade Unions', Journal of Labor Economics, 2 (1), 1-26.

Freeman, R. B. (1988), 'Contraction and Expansion: The Divergence of Private Sector and Public Sector Unionism in the United States', Journal of Economic Perspectives, 2 (2) 63-88.

Freeman, R. B. (1995), 'Are Your Wages Set In Beijing?', Journal of Economic Perspectives, 9 (3), 15-32.

Freeman, R. B., and L. Katz (eds.) (1995). Differences and Changes in Wage Structures. Chicago, Ill.: University of Chicago Press for NBER. 
Freeman, R. B. and J. Medoff (1984), What Do Unions Do?, New York: Basic Books.

Golden, Miriam, Peter Lange, and Michael Wallerstein (1997), 'Union Centralization Among Advanced Industrial Societies: An Empirical Study', dataset available at http://www.shelley.polisci.ucla.edu/data.

Gottschalk, P. (1993), 'Changes in Inequality of Family Income in Seven Industrialized Countries', American Economic Review, 83 (2), 136-142.

Grant, D. (2001), 'A Comparison of the Cyclical Behavior of Union and Nonunion Wages in the United States', Journal of Human Resources, 36 (1), 31-57.

Grant, E. K., R. Swidinsky, and J. Vanderkamp (1987), 'Canadian Union-Nonunion Wage Differentials', Industrial and Labor Relations Review, 41 (1), 93-107.

Green, F. (1988), 'The Trade Union Wage Gap in Britain: Some Recent Estimates', Economics Letters, 27 (2), 183-187.

Hildreth, A. K. G. (1999), 'What Has Happened to the Union Wage Differential in Britain in the 1990s?', Oxford Bulletin of Economics and Statistics, 61 (1), 5-31.

Hildreth, A. K. G. (2000), 'Union Wage Differentials For Covered Members And Non-Members In Great Britain', Journal of Labor Research, 21 (1), 133-147.

Hirsch, B.T. and D. A. Macpherson (2002), Union Membership and Earnings Data Book: Compilations from the Current Population Survey (2002 Edition). Washington: Bureau of National Affairs.

Hirsch, B. T., D. A. Macpherson, and E. J. Schumacher (2002), 'Measuring Union and NonUnion Wage Growth: Puzzles in Search of Solutions', paper presented at the $23^{\text {rd }}$ Middlebury Economics Conference, Changing Role of Unions, Middlebury, Vermont, April.

Hirsch, B. T., D. A. Macpherson, and W. G. Vroman (2001), 'Estimates of Union Density by State', Monthly Labor Review, 124 (7), 51-55.

Hirsch, B. T., and E. J. Schumacher (1998), 'Unions, Wages, and Skills', Journal of Human Resources, 33 (1), 201-219.

Hirsch, B. T. and E. J. Schumacher (2002), 'Match Bias In Wage Gap Estimates Due To Earnings Imputation', Mimeograph, Trinity University, available at www.trinity.edu/bhirsch/or www.ssrn.com.

Jarrell, S. B. and T. D. Stanley, (1990), 'A Meta-Analysis of the Union-Nonunion Wage Gap', Industrial and Labor Relations Review, 44 (1), 54-67. 
Katz, L., G. Loveman, and D. G. Blanchflower (1995), 'A Comparison of Changes in the Structure of Wages in Four OECD Countries', in R. B. Freeman and L. F. Katz (eds.) Differences and Changes in Wage Structures, Chicago, Ill.: University of Chicago Press for NBER, pp. 25-65.

Kaufman, B.E. (2002), 'Models of Union Wage Determination: What Have We Learned Since Dunlop and Ross?', Industrial Relations, 41 (1), 110-158.

Kornfeld, R. (1993), 'The Effects of Union Membership on Wages and Employee Benefits: The Case of Australia', Industrial and Labor Relations Review, 47 (1), 114-128.

Kuhn, P. (1998), 'Unions and the Economy: What We Know; What We Should Know', Canadian Journal of Economics, 31 (5), 1033-1056.

Kuhn, P., and A. Sweetman (1998), 'Wage Loss Following Displacement: The Role of Union Coverage', Industrial and Labor Relations Review, 51 (3), 384-400.

Kuhn, P., and A. Sweetman (1999), 'Vulnerable Seniors: Unions, Tenure, and Wages Following Permanent Job Loss', Journal of Labor Economics, 17 (4), 671-693.

Lanot, G., and I. Walker (1998), 'The Union/Non-Union Wage Differential: An Application of Semi-Parametric Methods', Journal of Econometrics, 84 (2), 327-349.

Lemieux, T. (1998), 'Estimating the Effects of Unions on Wage Inequality in a Panel Data Model with Comparative Advantage and Non-Random Selection,' Journal of Labor Economics, $16(2), 261-291$.

Levy, P. A. (1985), 'The Unidimensional Perspective of the Reagan Labor Act', Rutgers Law Journal, 16 (2), 269-390.

Lewis, H. G. (1963), Unionism and Relative Wages in the United States, Chicago, Ill.: University of Chicago Press.

Lewis, H. G. (1986), Union Relative Wage Effects: A Survey, Chicago, Ill.: University of Chicago Press.

Linneman, P. D., M. L. Wachter, and W. H. Carter (1990), 'Evaluating the Evidence on Union Employment and Wages', Industrial and Labor Relations Review, 44 (1), 34-53.

MacDonald, G. M., and J. C. Evans (1981), 'The Size and Structure of Union-Non-Union Wage Differentials in Canadian Industry', Canadian Journal of Economics, 14 (2), 216-231.

Machin, S. (2001), 'Does It Still Pay To Be In Or To Join A Union?' Working Paper, University College London. 
Machin, S., M. B. Stewart, and J. Van Reenen (1993), 'The Economic Effects of Multiple Unionism', Scandinavian Journal of Economics, 95 (3), 275-292.

Macpherson, D. A., and J. B. Stewart (1990), 'The Effect of International Competition on Union and Non-Union Wages', Industrial and Labor Relations Review, 43 (4), 434-446.

Main, B. (1996), 'The Union Relative Wage Gap', in D. Gallie, R. Penn and M. Rose (eds.), Trade Unionism in Recession, Oxford: Oxford University Press, pp. 216-243.

Main, B., and B. Reilly (1992), 'Women and the Union Wage Gap', Economic Journal, 102 (410), 49-66.

Main, B., and B. Reilly (1993), 'The Employer Size-Wage Gap: Evidence for Britain', Economica, 60 (238), 125-142.

Maloney, T. (1997), Benefit Reform and Labour Market Behaviour in New Zealand, Institute of Policy Studies, Victoria University, Wellington, New Zealand.

Maloney, T. (1998), Five Years After: The New Zealand Labour Market and the Employment Contracts Act, Institute of Policy Studies, Victoria University, Wellington, New Zealand.

Maloney, T., and J. Savage (1996), 'Labour Markets and Policy', in B. Silverstone, A. Bollard, and R. Lattimore (eds.), A Study of Economic Reform: The Case of New Zealand, Amsterdam: Elsevier Science, pp. 173-213.

Mellow, W., and H. Sider (1983), 'Accuracy of Response in Labor Market Surveys: Evidence and Implications', Journal of Labor Economics, 1 (4), 331-344.

Metcalf, D., and M. B. Stewart (1992), 'Closed Shops and Relative Pay: Institutional Arrangements or High Density?', Oxford Bulletin of Economics and Statistics, 54 (4), 503-516.

Metcalf, D., K. Hansen, and A. Charlwood (2001), 'Unions and the Sword of Justice: Unions and Pay Systems, Pay Inequality, Pay Discrimination and Low Pay', National Institute Economic Review, 176 (2), 61-75.

Miller, P. and C. Mulvey (1996), 'Unions, Firms Size and Wages', The Economic Record, 72 (217), 138-152.

Millward, N., A. Bryson, and J. Forth (2000), All Change At Work?, London: Routledge.

Millward, N., J. Forth, and A. Bryson (2001), Who Calls the Tune at Work? The Impact of Unions on Jobs and Pay, York: Joseph Rowntree Foundation.

Mishel, L., and J. Bernstein (1994), The State of Working America, 1994-95, Economic Policy Institute series. Armonk, N.Y.: M.E. Sharpe. 
Moll, P. (1993), 'Black South African Unions: Relative Wage Effects in International Perspective', Industrial and Labor Relations Review, 46 (2), 245-262.

Moore, W. J., and J. Raisian (1980), 'Cyclical Sensitivity of Union/Non-Union Relative Wage Effects', Journal of Labor Research, 1 (1), 115-132.

Mulvey, C. (1986), 'Wage Levels: Do Unions Make a Difference?', in J. Niland (ed.), Wage Fixation in Australia, Sydney: Allen and Unwin, pp. 203-216.

Murphy, P. D., P. Sloane, and D. H. Blackaby (1992), 'The Effects of Trade Unions on the Distribution of Earnings: A Sample Selectivity Approach', Oxford Bulletin of Economics and Statistics, 54 (4), 517-542.

OECD (1996), Employment Outlook, Organisation of Economic Co-operation and Development, Paris, France.

Park, A., J. Curtice, K. Thomson, L. Jarvis, and C. Bromley (2001), British Social Attitudes, The $18^{\text {th }}$ Report: Public Policy, Social Ties, London: Sage Publications.

Park, Y. (1991), 'Union/Non-Union Wage Differentials in the Korean Manufacturing Sector', International Economic Journal, 5 (4), 79-91.

Raphael S. (2000), 'Estimating the Union Earnings Effect Using a Sample of Displaced Workers', Industrial and Labor Relations Review, 53 (3), 503-521.

Renaud, S. (1998), 'Unions, Wage and Total Compensation in Canada - An Empirical Study', Relations Industrielles - Industrial Relations, 53 (4), 710-729.

Reynolds, L., S. H. Masters, and C. H. Moser (1999), Labor Economics and Labor Relations, $11^{\text {th }}$ ed., Upper Saddle River, N.J.: Prentice Hall.

Robinson, C. (1989), 'The Joint Determination of Union Status and Union Wage Effects: Some Tests of Alternative Models', Journal of Political Economy, 97 (3), 639-667.

Robinson, C., and N. Tomes (1984), 'Union Wage Differentials in the Public and Private Sectors: A Simultaneous Equations Specification', Journal of Labor Economics; 2 (1), 106-127.

Schmidt, C. (1995), 'Relative Wage Effects of German Unions', Mimeograph, Selapo, University of Munich.

Schmidt, C., and K. F. Zimmermann (1991), 'Work Characteristics, Firm Size and Wages', Review of Economics and Statistics, 73 (4), 705-710.

Schumacher, E. J. (1999), 'What Explains Wage Differences between Union Members and Covered Non-Members?', Southern Economic Journal, 65 (3), 493-512. 
Schultz, T. P., and G. Mwabu (1998), 'Labor Unions and the Distribution of Wages and Employment in South Africa', Industrial and Labor Relations Review, 51 (4), 680-703.

Shah, A. (1984), 'Job Attributes and the Size of the Union/Non-Union Wage Differential', Economica, 51 (204), 437-446.

Simpson, W. (1985), 'The Impact of Unions on the Structure of Canadian Wages: An Empirical Analysis with Microdata', Canadian Journal of Economics, 18 (1), 164-181.

Stewart, M. B. (1983), 'Relative Earnings and Individual Union Membership in the United Kingdom', Economica, 50 (198), 111-125.

Stewart, M. B. (1987), 'Collective Bargaining Arrangements, Closed Shops and Relative Pay', Economic Journal, 97 (385), 140-156.

Stewart, M. B. (1990), 'Union Wage Differentials, Product Market Influences and the Division of Rents', Economic Journal, 100 (403), 1122-1137.

Stewart, M. B. (1991), 'Union Wage Differentials in the Face of Changes in the Economic and Legal Environment', Economica, 58 (230), 155-172.

Stewart, M. B. (1995), 'Union Wage Differentials in an Era of Declining Unionisation', Oxford Bulletin of Economics and Statistics, 57 (2), 143-166.

Swaffield, J. K. (2001), 'Does Measurement Error Bias Fixed-Effects Estimates of the Union Wage Effect?', Oxford Bulletin of Economics and Statistics, 63 (4), 437-457.

Symons, E., and I. Walker (1988), 'Union/Non-Union Wage Differentials, 1979-1984: Evidence from the UK Family Expenditure Surveys', Mimeograph, Keele University.

Troy, L. (2000), 'U.S. and Canadian Industrial Relations: Convergent or Divergent?', Industrial $\underline{\text { Relations, }} 39$ (4), 695-713.

Visser, J. (1996), 'Unionisation Trends Revisited', Working Paper, University of Amsterdam.

Wagner, J. (1991), Gewerkschaftsmitgliedschaft und Arbeitseinkommen in der Bundesrepublik Deutschland - Eine ökonometrische Analyse mit Inividualdaten', ifo-Studien, 37 (2), 109-140.

Wessels, W. (1994), 'Do Unionized Firms Hire Better Workers?', Economic Inquiry, 32 (4), 616-629.

Wooden, M. (2001), 'Union Wage Effects in the Presence of Enterprise Bargaining', Economic Record, 77 (236), 1-18.

Wooden, M., and B. Bora (1998), 'Workplace Characteristics and Their Effects on Wages: Australian Evidence', Australian Economic Papers, 38 (3), 276-289. 
Wunnava, P. V., and A. A. Okunade (1996), 'Countercyclical Union Wage Premium? Evidence for the 1980s', Journal of Labor Research, 17 (2), 289-296.

Yaron, G. (1990), ‘Trade Unions and Women's Relative Pay: A Theoretical and Empirical Analysis Using UK Data', Applied Economics Discussion Paper No. 95, Oxford University: Institute of Economics and Statistics 
Table 1

Union Wage Gaps for Various Countries, 1994-1999

\begin{tabular}{llcll}
\hline Country & \multicolumn{1}{c}{ Years } & Union coefficient & \multicolumn{1}{c}{$\mathbf{N}$} & Comments \\
\hline Australia & $1994,8 \& 9$ & $.118^{*}$ & 1,703 & \\
Austria & $1994,5,8 \& 9$ & $.150^{*}$ & 1,404 & \\
Brazil & 1999 & $.37^{*}$ & 803 & No education or private \\
Canada & $1997-9$ & $.083^{*}$ & 1682 & No private sector dummy \\
Chile & 1998,9 & $.159^{*}$ & 951 & \\
Cyprus & $1996-8$ & $.137^{*}$ & 1,272 & \\
Denmark & $1997-8$ & $.159^{*}$ & 1,058 & \\
France & $1996-8$ & .029 & 2,738 & \\
Germany & $1994-9$ & .037 & 4,115 & \\
Italy & $1994, \& 8$ & -.003 & 578 & \\
Japan & $1994-6,8,9$ & $.258^{*}$ & 2,505 & \\
Netherlands & $1994 \& 5$ & -.006 & 1,291 & \\
New Zealand & $1994-9$ & $.099^{*}$ & 2,784 & No private sector dummy \\
Norway & $1994-9$ & $.073^{*}$ & 4,666 & \\
Portugal & $1998-9$ & $.179^{*}$ & 970 & \\
Spain & $1995,7-9$ & $.069^{*}$ & 1,490 & No private sector dummy \\
Sweden & $1994-9$ & -.002 & 3,619 & \\
\hline
\end{tabular}

Notes: Dependent variable log of earnings variously defined. * indicates statistically significantly different from zero at the .05 level or better. Controls are age, age squared, years of schooling, private sector, hours and union status. Sample restricted to employees. Germany includes East and West.

Dependent variable defined as follows:

Australia

Austria

Canada

Chile

Cyprus

Denmark

France

Germany

Italy

Japan

Netherlands

New Zealand

Norway

Portugal

Southern Ireland

Spain

Sweden
Yearly income in Australian \$

Respondent's personal net income per month in Austrian Schilling

In what range would your own personal income fall in Canadian \$

Respondent's monthly net income in CLP

Monthly gross earnings before taxes in Cyprus Pounds

Respondent's earnings per year before taxes in DKK

Respondent's monthly earnings in Francs

Respondent's net earnings per month after taxes and social insurance in DM

Respondent's net income per month in thousands of Lira

How much did you earn yourself last year before taxes in thousands of Yen.

Respondent's income after taxes in Guilder

Yearly income from all sources before tax in N.Z. \$

Personal gross income before taxes and allowances in 1997, incl. retirement benefits. etc.

Respondent's monthly average net income in Escudos

Weekly gross income before taxes and social insurance in Pounds

R's monthly earnings in Pesetas

Approximate income per month before taxes in SEK.

Source: ISSP, 1994-99. 


\section{Table 2}

(a) Union Density Rates in European Countries, 1950-1998 (wage and salary workers)

\begin{tabular}{lccccccccc}
\hline & 1950 & 1960 & 1970 & 1975 & 1980 & 1985 & 1990 & 1995 & 1998 \\
\hline Austria & 62 & 60 & 57 & 53 & 52 & 52 & 47 & 41 & 39 \\
Denmark & 56 & 62 & 63 & 69 & 79 & 78 & 75 & 77 & 76 \\
France & 30 & 24 & 20 & 22 & 22 & 19 & 14 & 10 & 10 \\
Germany (West) & 38 & 35 & 32 & 35 & 35 & 34 & 32 & & \\
Germany & & & & & & & 36 & 29 & 26 \\
Italy & 45 & 28 & 37 & 48 & 50 & 42 & 39 & 39 & 38 \\
Netherlands & 43 & 42 & 37 & 38 & 35 & 28 & 24 & 24 & 23 \\
Norway & 45 & 52 & 50 & 52 & 55 & 56 & 56 & 55 & 55 \\
Portugal & & & & & 52 & & 40 & 30 & 25 \\
Spain & & & & 30 & 8 & 10 & 12 & 18 & 17 \\
Sweden & 67 & 71 & 67 & 73 & 78 & 82 & 82 & 88 & 86 \\
\hline
\end{tabular}

Sources: Ebbinghaus and Visser (2000); Blanchflower (1996)

(b) Union Density Rates in Non-European OECD countries

\begin{tabular}{lcccc}
\hline & 1970 & 1980 & 1990 & 1993 \\
\hline Australia & 44.2 & 49.9 & 40.8 & 35.0 \\
Canada & 31.0 & 36.1 & 35.8 & 37.4 \\
Japan & 34.7 & 30.8 & 25.2 & 24.2 \\
New Zealand & 40.8 & 47.7 & 45.5 & 30.1 \\
\hline
\end{tabular}

Source: Blanchflower (1996). 
Table 3

Union Coefficients in a Log Hourly Wage Equation for the US, 1973-2001

\begin{tabular}{|c|c|c|c|c|}
\hline \multirow[b]{2}{*}{ Year } & \multicolumn{2}{|c|}{ All sectors } & \multicolumn{2}{|c|}{ Private sector } \\
\hline & $\begin{array}{c}\text { Imputed + } \\
\text { Non-imputed }\end{array}$ & $\begin{array}{l}\text { Non-imputed } \\
\text { only }\end{array}$ & $\begin{array}{c}\text { Imputed + } \\
\text { Non-imputed }\end{array}$ & $\begin{array}{l}\text { Non-imputed } \\
\text { Only }\end{array}$ \\
\hline 1973 & .132 & .165 & .120 & .153 \\
\hline 1974 & .136 & .169 & .129 & .162 \\
\hline 1975 & .141 & .174 & .134 & .167 \\
\hline 1976 & .144 & .177 & .136 & .169 \\
\hline 1977 & .174 & .207 & .168 & .201 \\
\hline 1978 & .172 & .205 & .171 & .204 \\
\hline 1979 & .121 & .154 & .119 & .142 \\
\hline 1980 & .130 & .163 & .124 & .157 \\
\hline 1981 & .116 & .149 & .118 & .151 \\
\hline 1983 & .151 & .178 & .160 & .192 \\
\hline 1984 & .158 & .186 & .169 & .202 \\
\hline 1985 & .150 & .176 & .160 & .191 \\
\hline 1986 & .151 & .172 & .160 & .183 \\
\hline 1987 & .146 & .170 & .152 & .182 \\
\hline 1988 & .145 & .169 & .145 & .175 \\
\hline 1989 & .139 & .164 & .146 & .176 \\
\hline 1990 & .133 & .158 & .132 & .162 \\
\hline 1991 & .124 & .149 & .124 & .154 \\
\hline 1992 & .140 & .165 & .146 & .176 \\
\hline 1993 & .145 & .170 & .149 & .179 \\
\hline 1994 & .135 & .170 & .126 & .168 \\
\hline 1995 & .126 & .161 & .124 & .166 \\
\hline 1996 & .125 & .160 & .126 & .169 \\
\hline 1997 & .126 & .160 & .123 & .163 \\
\hline 1998 & .113 & .147 & .105 & 149 \\
\hline 1999 & .103 & .148 & .096 & .156 \\
\hline 2000 & .092 & .126 & .092 & .134 \\
\hline 2001 & .091 & .132 & .087 & .141 \\
\hline
\end{tabular}

Notes and Sources: Dependent variable is the log hourly wage.

a) 1973-1981 May CPS, $n=38,000$ for all sectors, and $n=31,000$ for the private sector. Controls comprise age, age ${ }^{2}$, male, union, years of education, 2 race dummies, 28 state dummies, usual hours, private sector and 50 industry dummies. For 1980 and 1981 sample sizes fall to approx. 16,000 because from 1980 only respondents in months 4 and 8 in the outgoing rotation groups report a wage. Since the May CPS sample files available to us do not include allocated earnings in 1973-81, the series in columns 2 and 4 are adjusted upward by the average bias of 0.033 found by Hirsch and Schumacher (2002) using these May CPS data for 1979-81.

b) Matched Outgoing Rotation Group files of the Current Population Survey (MORGs), 1983-2001. Controls comprise usual hours, age, age ${ }^{2}, 4$ race dummies, 15 highest qualifications dummies, male, union, 46 industry dummies, 4 organisational status dummies, and 50 state dummies. Sample is non-agricultural workers working at the time of interview, aged at least 16 years. For 1989-95 allocation flags are either unreliable (in 1989-93) or not available (1994 through August 1995). For 1989-93, the gaps are adjusted upward by the average imputation bias during 1983-88 (.031 in column 3). For 1994-95 the gap is adjusted upward by the bias during 1996-98 (.046 in column 3). 


\section{Table 4}

\section{Union Wage Gap Estimates for the United States, 1973-2001 (\%) (excludes workers with imputed earnings)}

\begin{tabular}{|l|c|c|c|}
\hline & All sectors & Private sector & Private sector \\
\hline Year & Blanchflower/Bryson & Blanchflower/Bryson & Hirsch/Schumacher \\
\hline 1973 & $17.9 \%$ & $16.5 \%$ & $17.5 \%$ \\
\hline 1974 & $18.4 \%$ & $17.6 \%$ & $17.5 \%$ \\
\hline 1975 & $19.0 \%$ & $18.2 \%$ & $19.2 \%$ \\
\hline 1976 & $19.4 \%$ & $18.4 \%$ & $20.4 \%$ \\
\hline 1977 & $23.0 \%$ & $22.3 \%$ & $23.9 \%$ \\
\hline 1978 & $22.8 \%$ & $22.6 \%$ & $22.8 \%$ \\
\hline 1980 & $16.6 \%$ & $15.3 \%$ & $21.3 \%$ \\
\hline 1981 & $17.7 \%$ & $17.0 \%$ & $20.4 \%$ \\
\hline 1983 & $16.1 \%$ & $16.3 \%$ & $25.5 \%$ \\
\hline 1984 & $19.5 \%$ & $21.2 \%$ & $26.2 \%$ \\
\hline 1985 & $20.4 \%$ & $22.4 \%$ & $26.0 \%$ \\
\hline 1986 & $19.2 \%$ & $21.0 \%$ & $23.9 \%$ \\
\hline 1987 & $18.8 \%$ & $20.1 \%$ & $24.0 \%$ \\
\hline 1988 & $18.5 \%$ & $20.0 \%$ & $22.6 \%$ \\
\hline 1989 & $18.4 \%$ & $19.1 \%$ & $24.5 \%$ \\
\hline 1990 & $17.8 \%$ & $19.2 \%$ & $22.5 \%$ \\
\hline 1991 & $17.1 \%$ & $17.6 \%$ & $22.0 \%$ \\
\hline 1992 & $16.1 \%$ & $16.6 \%$ & $22.5 \%$ \\
\hline 1993 & $17.9 \%$ & $19.2 \%$ & $23.5 \%$ \\
\hline 1994 & $18.5 \%$ & $19.6 \%$ & $25.2 \%$ \\
\hline 1995 & $18.5 \%$ & $18.2 \%$ & $24.5 \%$ \\
\hline 1996 & $17.4 \%$ & $18.0 \%$ & $23.5 \%$ \\
\hline 1997 & $17.4 \%$ & $18.4 \%$ & $23.2 \%$ \\
\hline 1998 & $17.4 \%$ & $17.7 \%$ & $22.4 \%$ \\
\hline 1999 & $15.8 \%$ & $16.1 \%$ & $22.0 \%$ \\
\hline 2000 & $16.0 \%$ & $16.9 \%$ & $20.4 \%$ \\
\hline 2001 & $13.4 \%$ & $14.3 \%$ & $20.0 \%$ \\
\hline $1973-2001$ average & $14.1 \%$ & $15.1 \%$ & $22.4 \%$ \\
\hline & $18.0 \%$ & $18.4 \%$ & \\
\hline
\end{tabular}

Notes: Wage gap estimates calculated taking anti-logs and deducting 1 . Columns 1 and 2 are taken from Table 3. Column 3 is taken from column 5 of Table 4 of Hirsch and Schumacher (2002).

Source: Data for 1973-81 are from the May CPS Earnings Supplements, and for 1983-2001 from the monthly CPSORG earnings files. The Hirsch and Schumacher (2002) sample includes employed private sector nonagricultural wage and salary workers aged 16 years and above with positive weekly earnings and non-missing data for control variables (few observations are lost). The wage gap reported in column 3 is the coefficient on a dummy variable for union membership in a regression where the log of hourly earnings is the dependent variable. The control variables included are years of schooling, experience and its square (allowed to vary by gender), and dummy variables for gender, race and ethnicity (3), marital status (2), part-time status, region (8), large metropolitan area, industry (8), and occupation (12). Because the sample does not include allocated earnings in 1973-78, the "not corrected" series are adjusted downwards by the average bias found during 1979-81 of .033 in column 3. All three columns include only workers reporting earnings. All allocated earners are identified and excluded for the years 1973-88 and 19962001. For 1989-95 allocation flags are either unreliable (in 1989-93) or not available (1994 through August 1995). 
For 1989-93, the gaps are adjusted upward by the average imputation bias during 1983-88 (.031 in column 3 ). For 1994-95 the gap is adjusted upward by the bias during 1996-98 (.046 in column 3). 


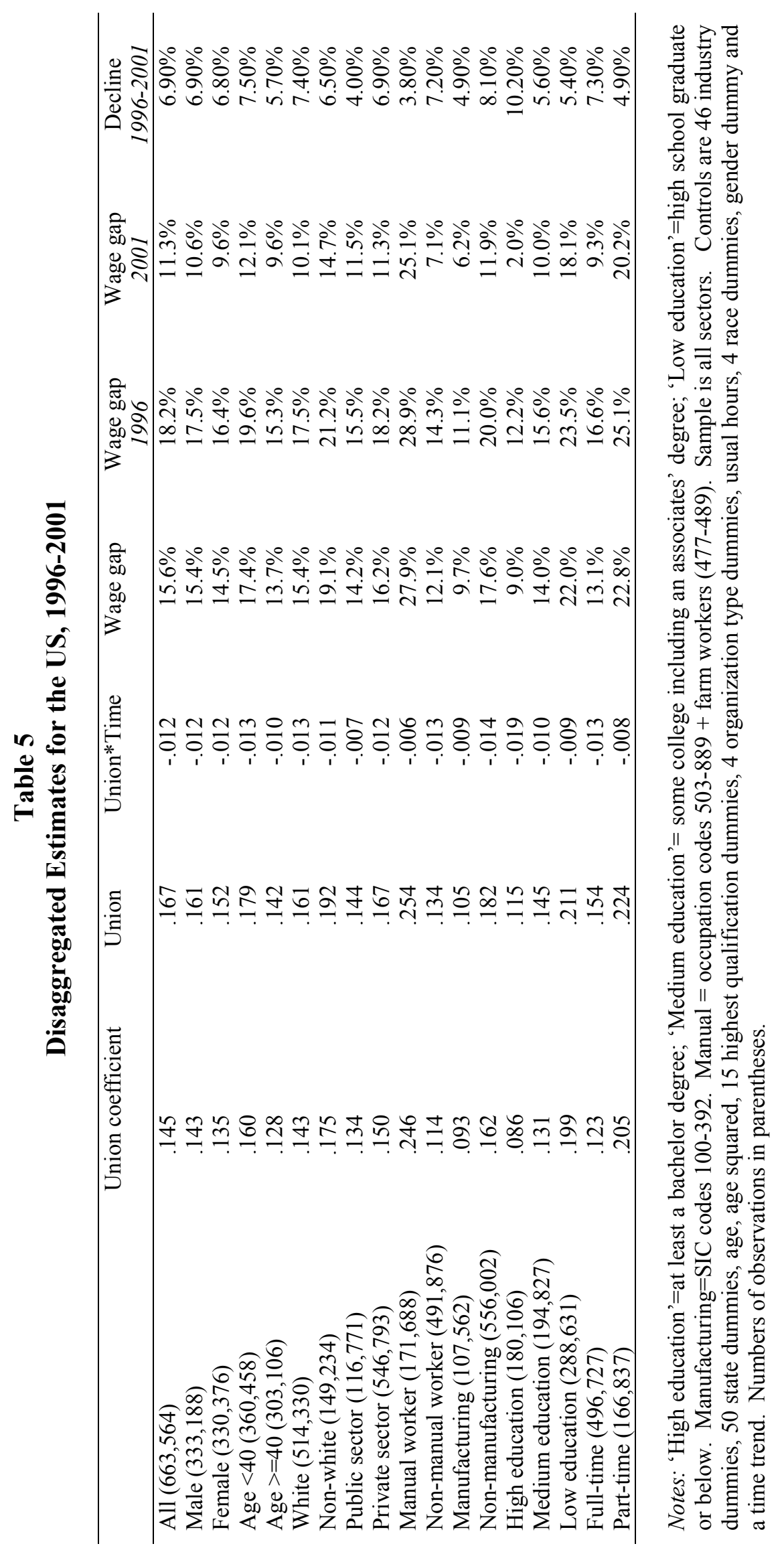


Table 6

Time-Series Estimates of Union Wage Gaps, UK

\begin{tabular}{lcc}
\hline & LFS & BSA \\
\hline 1985 & & $3.5 \%$ \\
& & $(768)$ \\
1986 & & $11.1 \%$ \\
& & $(1,418)$ \\
1987 & & $7.9 \%$ \\
1989 & & $(1,277)$ \\
& & $6.3 \%$ \\
1990 & & $(1,329)$ \\
1991 & & $6.3 \%$ \\
& & $(1,167)$ \\
1993 & $14.9 \%$ & $4.8 \%$ \\
1994 & $(8,391)$ & $(1,097)$ \\
& $17.5 \%$ & $11.4 \%$ \\
1995 & $(8,301)$ & $(1,032)$ \\
1996 & $14.6 \%$ & $13.7 \%$ \\
1997 & $(9,008)$ & $(1,345)$ \\
& $14.8 \%$ & $13.1 \%$ \\
1998 & $(9,029)$ & $(1,359)$ \\
1999 & $11.4 \%$ & $7.3 \%$ \\
2000 & $(18,227)$ & $(1,432)$ \\
& $12.2 \%$ & $17.7 \%$ \\
& $(18,409)$ & $(506)$ \\
& $10.2 \%$ & $11.0 \%$ \\
& $(17,357)$ & $(1,336)$ \\
& $10.3 \%$ & $9.5 \%$ \\
& $(16,132)$ & $(1,271)$ \\
& & $5.0 \%$ \\
& & $(1,426)$ \\
& & $4.4 \%$ \\
& & $(1,417)$ \\
\hline
\end{tabular}

Sources: Data in the first column are from the UK Labour Force Surveys. The controls comprise industry dummies, region dummies, age, age squared, highest qualification dummies, workplace size dummies, usual hours, race dummies, and a gender dummy. Data in the second column are from the British Social Attitudes Surveys. Controls are gender, age, ethnicity, qualifications, manual worker, full-time worker, establishment size, public sector, manufacturing, and region. The BSAS estimates for 1994 and 1995 exclude the public sector dummy because this was not available in that year, while the 1991 estimates exclude the ethnic minority dummy due to the low number of valid cases with ethnicity in that year. In both series, the dependent variable is the log of the hourly wage. In the BSAS this is derived from the annual banded earnings data by taking the mid-point of the respondent's earnings band and dividing this by continuous hours worked. (The earnings band for the top-coded highest earners is closed by introducing an upper ceiling which is 1.5 times the lower band.) Before 1996, the BSAS hours worked question did not explicitly mention overtime hours. The hours denominator used here explicitly includes overtime hours from 1996 onwards. No BSAS surveys were conducted in 1988 and 1992. Numbers of observations are given in parentheses. 


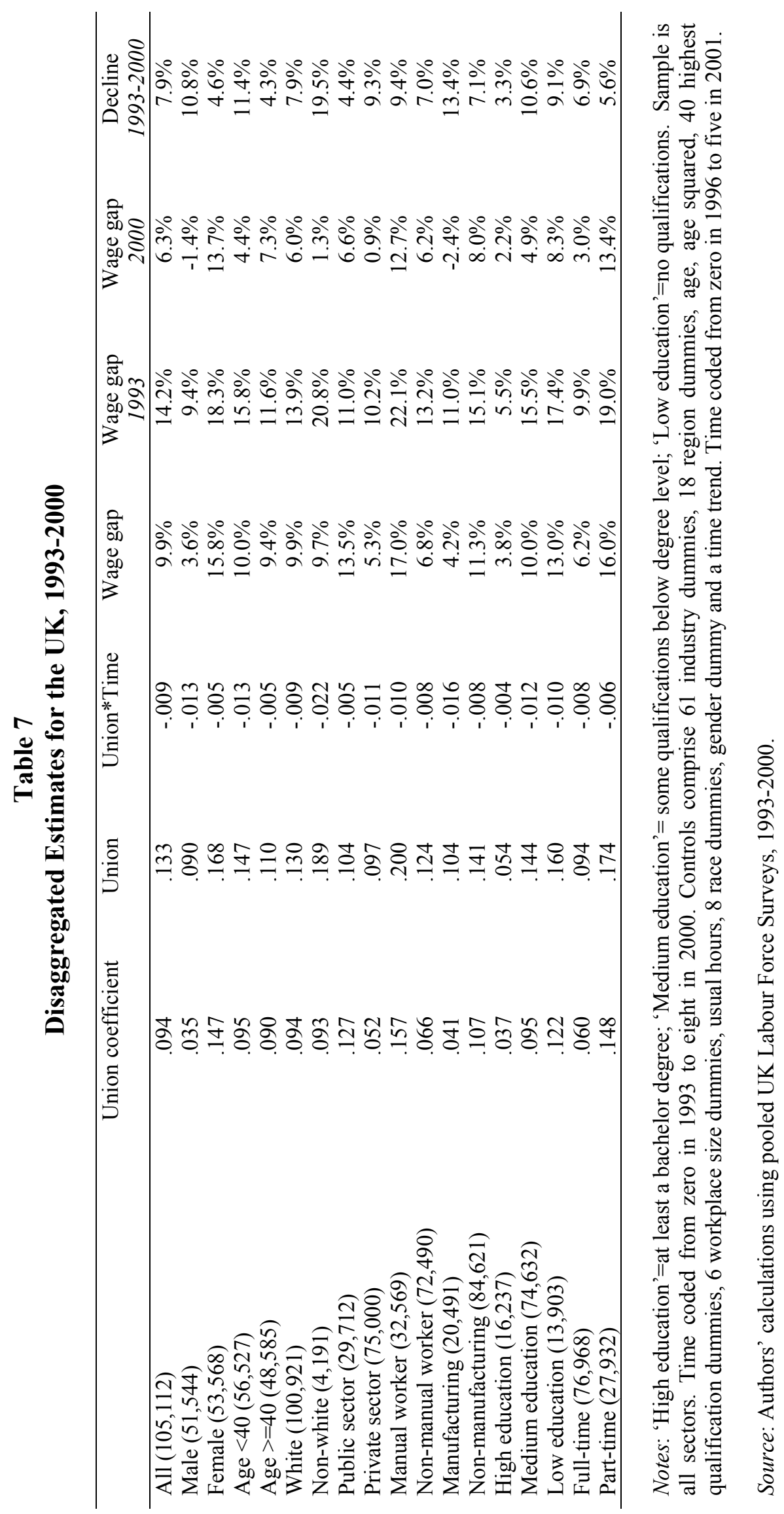




\section{Table 8}

\section{Disaggregated Estimates of the Union Hourly Wage Premium in Britain, 1985-2001}

\begin{tabular}{lccc}
\hline & $\mathrm{M}(1): 1985-2001$ & $\mathrm{M}(2): 1993-1995$ & $\mathrm{M}(3): 1999-2001$ \\
\hline Whole sample & $9.1 \%(17,934)$ & $12.2 \%(3,756)$ & $5.1 \%(3947)$ \\
Men & $6.1 \%(8,969)$ & $11.5 \%(1,829)$ & $1.8 \%(1,898)$ \\
Women & $11.2 \%(8,965)$ & $11.6 \%(1,927)$ & $7.5 \%(2,049)$ \\
Age $<45$ years & $9.4 \%(12,082)$ & $11.6 \%(2,557)$ & $2.4 \%(2,681)$ \\
Age 45+ years & $8.2 \%(5,852)$ & $13.0 \%(1,199)$ & $10.1 \%(1,266)$ \\
Private sector & $7.1 \%(10,463)$ & $10.1 \%(696)$ & $3.6 \%(2,811)$ \\
Public sector & $10.0 \%(4,748)$ & $14.7 \%(337)$ & $10.6 \%(1,136)$ \\
Manual worker & $15.0 \%(6,925)$ & $19.2 \%(1,406)$ & $11.7 \%(1,410)$ \\
Non-manual & $5.6 \%(11,009)$ & $8.4 \%(2,350)$ & $2.0 \%(2,537)$ \\
Manufacturing & $9.6 \%(3,973)$ & $13.1 \%(742)$ & $10.0 \%(770)$ \\
Non-manufacturing & $8.5 \%(13,961)$ & $12.1 \%(3,014)$ & $4.3 \%(3,177)$ \\
High education & $4.7 \%(5,694)$ & $8.5 \%(1,166)$ & $-0.9 \%(1,443)$ \\
Medium education & $9.4 \%(6,545)$ & $10.6 \%(1,489)$ & $8.1 \%(1,503)$ \\
Low education & $11.3 \%(5,536)$ & $17.5 \%(1,056)$ & $9.0 \%(965)$ \\
Full-timer & $8.0 \%(14,237)$ & $11.9 \%(2,952)$ & $3.3 \%(3,065)$ \\
Part-timer & $14.6 \%(3,697)$ & $15.0 \%(804)$ & $13.7 \%(882)$ \\
\hline
\end{tabular}

Notes:

a. Coefficients are exponentiated, depicting the difference in log gross hourly wages between members and nonmembers, expressed as a percentage of non-members' wages. Figures in parentheses are the number of observations in the model.

b. The figures are derived from the union membership dummy coefficient in pooled regressions for the years stated. Specification M(1) pools the data for 1985-2001 and (where the sub-groups do not preclude their inclusion) they contain the following controls: grouped years, gender, age, qualifications, manual worker, fulltime worker, establishment size, manufacturing, region, grouped year dummies. $M(2)$ is the same as $M(1)$, but excluding the grouped year variables, for the period 1993-95; M(3) performs the same calculation for the most recent period, 1999-2001.

c. Surveys in 1994 and 1995 did not collect information on sector, so M(2) for public and private sector equations is run for the 1993 data only. We tested the sensitivity of results to the inclusion of a public sector dummy in models. Where significant, these are reported in the text.

d. All estimates are based on unweighted data.

e. The dependent variable is the log of the hourly wage. Using the mid-point methodology, this is derived from the annual banded earnings data by taking the mid-point of the respondent's earnings band and dividing this by continuous hours worked. (The earnings band for the top-coded highest earners is closed by introducing an upper ceiling which is 1.5 times the lower band.) Before 1996 the BSAS hours worked question did not explicitly mention overtime hours. The hours denominator used here explicitly includes overtime hours from 1996 onwards.

f. No surveys were conducted in 1988 and 1992.

Source: Authors' calculations using pooled British Social Attitudes Surveys, 1985-2001. 


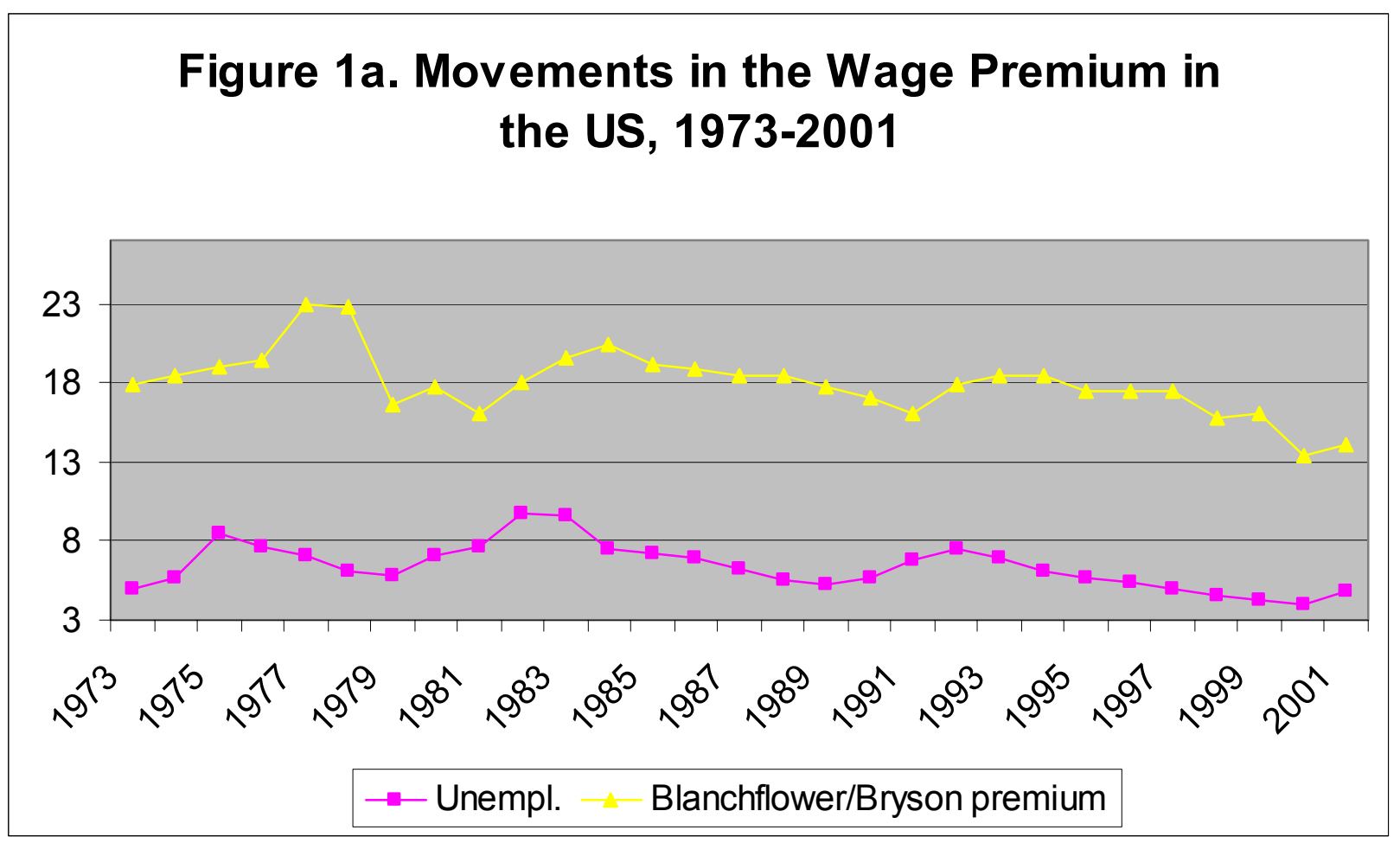


57

Figure lb. Movements in the Wage Premium in Britain, 1985-2001

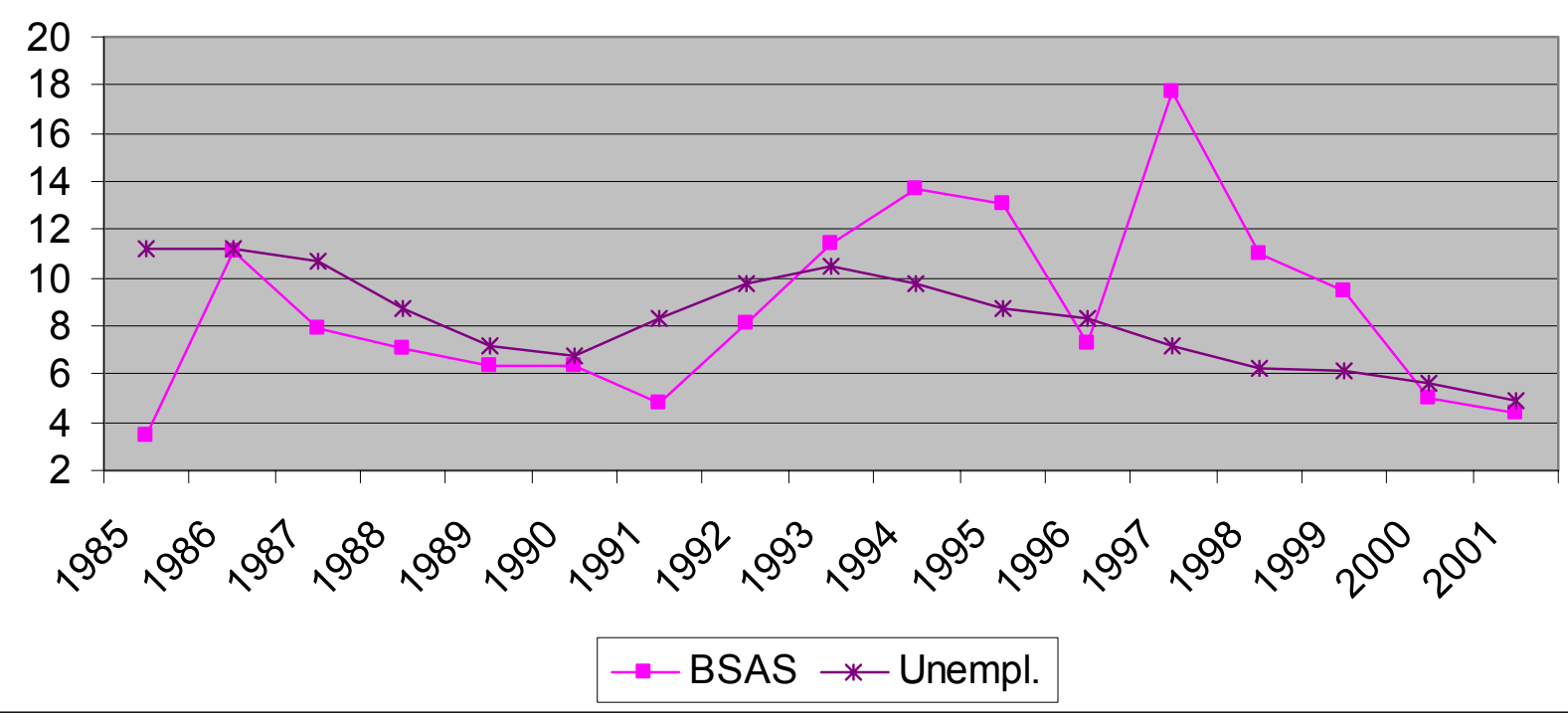


Appendix Table 1 Union Density and Unemployment in the UK and the US, 1964-2001

\begin{tabular}{|c|c|c|c|c|}
\hline & \multicolumn{2}{|c|}{ Union density (\%) } & \multicolumn{2}{|c|}{ Unemployment rate (\%) } \\
\hline & US & UK & US & UK \\
\hline 1964 & 29.3 & 44.1 & 5.2 & \\
\hline 1965 & 28.9 & 44.2 & 4.5 & \\
\hline 1966 & 28.4 & 43.6 & 3.8 & \\
\hline 1967 & 28.3 & 43.7 & 3.8 & \\
\hline 1968 & 28.2 & 44.0 & 3.6 & \\
\hline 1969 & 28.0 & 45.3 & 3.5 & \\
\hline 1970 & 27.8 & 48.5 & 4.9 & \\
\hline 1971 & 27.2 & 48.7 & 5.9 & 2.4 \\
\hline 1972 & 26.6 & 49.5 & 5.6 & 2.7 \\
\hline 1973 & 26.6 & 49.3 & 4.9 & 1.9 \\
\hline 1974 & 26.2 & 50.4 & 5.6 & 1.9 \\
\hline 1975 & 24.6 & 51.7 & 8.5 & 2.9 \\
\hline 1976 & 24.5 & 52.0 & 7.7 & 3.9 \\
\hline 1977 & 24.1 & 53.6 & 7.1 & 4.2 \\
\hline 1978 & 23.4 & 54.3 & 6.1 & 4.1 \\
\hline 1979 & 24.4 & 54.5 & 5.8 & 3.8 \\
\hline 1980 & 23.3 & 52.8 & 7.1 & 4.8 \\
\hline 1981 & 21.7 & 49.9 & 7.6 & 7.6 \\
\hline 1982 & 21.0 & 47.9 & 9.7 & 9.0 \\
\hline 1983 & 20.3 & 46.7 & 9.6 & 9.9 \\
\hline 1984 & 19.1 & 45.3 & 7.5 & 10.1 \\
\hline 1985 & 18.2 & 44.0 & 7.2 & 10.3 \\
\hline 1986 & 17.7 & 42.8 & 7.0 & 10.5 \\
\hline 1987 & 17.3 & 42.8 & 6.2 & 9.4 \\
\hline 1988 & 17.0 & 42.2 & 5.5 & 7.6 \\
\hline 1989 & 16.6 & 41.5 & 5.3 & 5.9 \\
\hline 1990 & 16.3 & 40.1 & 5.6 & 5.5 \\
\hline 1991 & 16.3 & 38.2 & 6.8 & 7.6 \\
\hline 1992 & 16.0 & 36.1 & 7.5 & 9.2 \\
\hline 1993 & 16.0 & 35.4 & 6.9 & 9.7 \\
\hline 1994 & 15.7 & 33.9 & 6.1 & 8.8 \\
\hline 1995 & 15.1 & 32.3 & 5.6 & 7.6 \\
\hline 1996 & 14.7 & 31.5 & 5.4 & 7.0 \\
\hline 1997 & 14.2 & 30.4 & 4.9 & 5.3 \\
\hline 1998 & 14.1 & 29.9 & 4.5 & 4.5 \\
\hline 1999 & 14.0 & 29.6 & 4.2 & 4.2 \\
\hline 2000 & 13.6 & 29.5 & 4.0 & 3.6 \\
\hline 2001 & 13.5 & 29.1 & 4.8 & 3.2 \\
\hline
\end{tabular}

Notes and Sources:

a. US: The 1983-2000 Current Population Survey Outgoing Rotation Group (CPS-ORG) earnings files, the May 1973-81 CPS earnings files, and the Directory of National Unions and Employee Associations, various years. Hirsch, Macpherson, and Vroman (2001). 2001 number from BLS

(http://stats.bls.gov/news.release/union2.nr0.htm), nonagricultural wage and salary workers.

b. UK: 1964-92, Visser (1996) and Golden, Lange, and Wallerstein (1997). From 1995, source is Brook (2002). Figures for 1993 and 1994 are authors' interpolations using overlap in the Visser and Brook series in 1991 and 1992 for the UK and Britain. UK figures are union density among employees in employment. UK unemployment is based on the ILO definition 
Appendix Table 2

Income Inequality Measures

\begin{tabular}{|c|c|c|c|c|c|}
\hline Country & Year & Gini coefficient & $\begin{array}{l}\text { Percentile } \\
\text { ratio } \\
(90 / 10)\end{array}$ & $\begin{array}{c}\text { Percentile } \\
\text { ratio } \\
(90 / 50)\end{array}$ & $\begin{array}{c}\text { Percentile } \\
\text { ratio } \\
(80 / 20)\end{array}$ \\
\hline Australia & 1981 & 0.281 & 3.93 & 1.86 & 2.48 \\
\hline Australia & 1985 & 0.292 & 3.97 & 1.87 & 2.55 \\
\hline Australia & 1989 & 0.304 & 4.19 & 1.94 & 2.59 \\
\hline Australia & 1994 & 0.311 & 4.33 & 1.95 & 2.76 \\
\hline Austria & 1987 & 0.227 & 2.89 & 1.62 & 1.98 \\
\hline Austria & 1995 & 0.277 & 3.73 & 1.79 & 2.33 \\
\hline Belgium & 1985 & 0.227 & 2.73 & 1.62 & 1.96 \\
\hline Belgium & 1988 & 0.232 & 2.77 & 1.63 & 1.97 \\
\hline Belgium & 1992 & 0.224 & 2.76 & 1.62 & 1.96 \\
\hline Belgium & 1997 & 0.255 & 3.26 & 1.73 & 2.16 \\
\hline Canada & 1971 & 0.316 & 4.79 & 1.89 & 2.70 \\
\hline Canada & 1975 & 0.289 & 4.27 & 1.80 & 2.44 \\
\hline Canada & 1981 & 0.284 & 4.05 & 1.83 & 2.42 \\
\hline Canada & 1987 & 0.283 & 3.89 & 1.84 & 2.35 \\
\hline Canada & 1991 & 0.281 & 3.78 & 1.82 & 2.33 \\
\hline Canada & 1994 & 0.285 & 3.87 & 1.85 & 2.39 \\
\hline Canada & 1997 & 0.291 & 4.01 & 1.86 & 2.45 \\
\hline Canada & 1998 & 0.305 & 4.13 & 1.88 & 2.51 \\
\hline Denmark & 1987 & 0.254 & 3.22 & 1.60 & 2.12 \\
\hline Denmark & 1992 & 0.236 & 2.85 & 1.55 & 2.02 \\
\hline Denmark & 1995 & 0.263 & 3.18 & 1.63 & 2.19 \\
\hline Denmark & 1997 & 0.257 & 3.15 & 1.62 & 2.18 \\
\hline Finland & 1987 & 0.209 & 2.59 & 1.51 & 1.86 \\
\hline Finland & 1991 & 0.210 & 2.63 & 1.53 & 1.83 \\
\hline Finland & 1995 & 0.226 & 2.68 & 1.59 & 1.90 \\
\hline France & 1979 & 0.293 & 3.47 & 1.87 & 2.22 \\
\hline France & 1981 & 0.288 & 3.40 & 1.88 & 2.25 \\
\hline France & 1984 & 0.292 & 3.46 & 1.93 & 2.27 \\
\hline France & 1989 & 0.287 & 3.46 & 1.82 & 2.24 \\
\hline France & 1994 & 0.288 & 3.54 & 1.91 & 2.23 \\
\hline Germany & 1973 & 0.271 & 3.22 & 1.81 & 2.12 \\
\hline Germany & 1978 & 0.264 & 3.11 & 1.78 & 2.06 \\
\hline Germany & 1981 & 0.244 & 2.89 & 1.79 & 2.03 \\
\hline Germany & 1983 & 0.260 & 3.11 & 1.79 & 2.10 \\
\hline Germany & 1984 & 0.249 & 3.01 & 1.71 & 2.06 \\
\hline Germany & 1989 & 0.247 & 2.94 & 1.70 & 1.99 \\
\hline Germany & 1994 & 0.261 & 3.18 & 1.74 & 2.10 \\
\hline Italy & 1986 & 0.306 & 4.05 & 1.97 & 2.51 \\
\hline Italy & 1991 & 0.289 & 3.76 & 1.85 & 2.49 \\
\hline Italy & 1995 & 0.342 & 4.77 & 2.02 & 2.76 \\
\hline Netherlands & 1983 & 0.260 & 2.94 & 1.86 & 2.10 \\
\hline Netherlands & 1987 & 0.256 & 2.94 & 1.82 & 2.07 \\
\hline Netherlands & 1991 & 0.266 & 3.02 & 1.73 & 2.11 \\
\hline Netherlands & 1994 & 0.253 & 3.15 & 1.73 & 2.15 \\
\hline Norway & 1979 & 0.223 & 2.76 & 1.58 & 1.88 \\
\hline Norway & 1986 & 0.233 & 2.92 & 1.62 & 1.96 \\
\hline Norway & 1991 & 0.231 & 2.79 & 1.58 & 1.90 \\
\hline Norway & 1995 & 0.238 & 2.83 & 1.57 & 1.95 \\
\hline
\end{tabular}




\begin{tabular}{llllll} 
Spain & 1980 & 0.318 & 4.37 & 2.02 & 2.60 \\
Spain & 1990 & 0.303 & 3.96 & 1.97 & 2.46 \\
Sweden & 1975 & 0.215 & 2.73 & 1.53 & 1.92 \\
Sweden & 1981 & 0.197 & 2.43 & 1.51 & 1.76 \\
Sweden & 1987 & 0.218 & 2.71 & 1.51 & 1.89 \\
Sweden & 1992 & 0.229 & 2.78 & 1.59 & 1.91 \\
Sweden & 1995 & 0.221 & 2.61 & 1.56 & 1.76 \\
UK & 1969 & 0.267 & 3.23 & 1.84 & 2.17 \\
UK & 1974 & 0.268 & 3.41 & 1.76 & 2.21 \\
UK & 1979 & 0.270 & 3.53 & 1.80 & 2.34 \\
UK & 1986 & 0.303 & 3.79 & 1.94 & 2.53 \\
UK & 1991 & 0.336 & 4.67 & 2.06 & 2.95 \\
UK & 1995 & 0.344 & 4.57 & 2.10 & 2.84 \\
US & 1974 & 0.318 & 4.92 & 1.90 & 2.65 \\
US & 1979 & 0.301 & 4.67 & 1.86 & 2.64 \\
US & 1986 & 0.335 & 5.71 & 2.04 & 3.04 \\
US & 1991 & 0.336 & 5.55 & 2.06 & 3.03 \\
US & 1994 & 0.355 & 5.85 & 2.15 & 3.11 \\
US & 1997 & 0.372 & 5.57 & 2.14 & 3.03 \\
\hline
\end{tabular}

Source: Luxembourg Income Study; downloadable at http://www.lisproject.org/keyfigures/ineqtable.htm All figures relate to disposable income. 
Appendix Table 3

Log Hourly Earnings Equations for the US, 1996-2001

\begin{tabular}{|c|c|c|c|c|c|}
\hline & $\begin{array}{l}(1) \\
\text { All } \\
\end{array}$ & $\begin{array}{c}(2) \\
\text { Private sector }\end{array}$ & $\begin{array}{c}\text { (3) } \\
\text { Public sector }\end{array}$ & $\begin{array}{l}\text { (4) } \\
\text { Men }\end{array}$ & $\begin{array}{c}(5) \\
\text { Women }\end{array}$ \\
\hline \multirow[t]{2}{*}{ Union } & .145 & .150 & .134 & .143 & .135 \\
\hline & (85.18) & (68.85) & (47.03) & (61.85) & (52.97) \\
\hline \multirow[t]{2}{*}{ Age } & .045 & .045 & .0478 & .055 & .036 \\
\hline & (173.5) & $(158.2)$ & (73.14) & $(143.3)$ & (103.7) \\
\hline \multirow[t]{2}{*}{$\operatorname{Age}^{2}$} & -.0005 & -.0005 & -.0005 & -.0006 & -.0004 \\
\hline & (146.5) & (134.5) & (60.64) & (120.7) & (88.30) \\
\hline \multirow[t]{2}{*}{ Male } & .151 & .157 & .123 & $\mathrm{~N} / \mathrm{a}$ & $\mathrm{n} / \mathrm{a}$ \\
\hline & (126.0) & (116.5) & (47.33) & & \\
\hline \multirow[t]{2}{*}{ State government } & -.145 & $\mathrm{n} / \mathrm{a}$ & -.141 & -.149 & -.147 \\
\hline & (36.41) & & (34.01) & (25.71) & (26.58) \\
\hline Local government & $\begin{array}{r}-.131 \\
(34.79)\end{array}$ & $\mathrm{n} / \mathrm{a}$ & $\begin{array}{r}-.138 \\
(34.04)\end{array}$ & $\begin{array}{r}-.137 \\
(25.40)\end{array}$ & $\begin{array}{r}-.133 \\
(24.85)\end{array}$ \\
\hline Private for profit & $\begin{array}{r}-.077 \\
(21.04)\end{array}$ & $\begin{array}{r}.080 \\
(30.47)\end{array}$ & $\mathrm{n} / \mathrm{a}$ & $\begin{array}{r}-.031 \\
(6.14)\end{array}$ & $\begin{array}{r}-.120 \\
(22.89)\end{array}$ \\
\hline Private non-profit & $\begin{array}{r}-.165 \\
(39.94)\end{array}$ & $\mathrm{n} / \mathrm{a}$ & $\mathrm{n} / \mathrm{a}$ & $\begin{array}{r}-.222 \\
(34.81)\end{array}$ & $\begin{array}{r}-.157 \\
(6.42)\end{array}$ \\
\hline Black & $\begin{array}{r}-.009 \\
(7.20)\end{array}$ & $\begin{array}{r}-.012 \\
(7.93)\end{array}$ & $\begin{array}{r}-.009 \\
(2.99)\end{array}$ & $\begin{array}{r}-.015 \\
(7.71)\end{array}$ & $\begin{array}{c}-.004 \\
(2.09)\end{array}$ \\
\hline American Indian & $\begin{array}{r}-.052 \\
(9.66)\end{array}$ & $\begin{array}{r}-.082 \\
(12.25)\end{array}$ & $\begin{array}{r}.015 \\
(1.65)\end{array}$ & $\begin{array}{r}-.075 \\
(9.51)\end{array}$ & $\begin{array}{c}-.032 \\
(4.36)\end{array}$ \\
\hline Asian or Pacific Islander & $\begin{array}{r}-.101 \\
(31.61)\end{array}$ & $\begin{array}{r}-.105 \\
(30.27)\end{array}$ & $\begin{array}{r}-.079 \\
(10.04)\end{array}$ & $\begin{array}{r}-.120 \\
(26.62)\end{array}$ & $\begin{array}{r}-.075 \\
(16.89)\end{array}$ \\
\hline Hispanic & $\begin{array}{r}-.112 \\
(50.42)\end{array}$ & $\begin{array}{r}-.125 \\
(51.81)\end{array}$ & $\begin{array}{l}-.033 \\
(5.89)\end{array}$ & $\begin{array}{r}-.130 \\
(42.21)\end{array}$ & $\begin{array}{r}-.090 \\
(28.17)\end{array}$ \\
\hline Usual hours & $\begin{array}{r}.004 \\
(76.00)\end{array}$ & $\begin{array}{r}.005 \\
(76.70)\end{array}$ & $\begin{array}{r}.002 \\
(11.65)\end{array}$ & $\begin{array}{r}.003 \\
(40.77)\end{array}$ & $\begin{array}{r}.005 \\
(63.43)\end{array}$ \\
\hline $\mathrm{N}$ & 663,564 & 546,793 & 116,771 & 333,188 & 330,376 \\
\hline $\mathrm{R}^{2}$ & .4655 & .4609 & .4546 & .4581 & .4436 \\
\hline Adjusted $\mathrm{R}^{2}$ & .4654 & .4607 & .4540 & .4579 & .4434 \\
\hline
\end{tabular}

Notes: All equations also include time 15 schooling dummies, 50 state dummies and 50 industry dummies. Excluded categories are federal government and white. Private sector excludes the self-employed. $|t|$-statistics are given in parentheses.

Source: CPS Matched Outgoing Rotation Group (MORG) files. 
Appendix Table 4

Log Hourly Earnings Equations for the UK, 1993-2000

\begin{tabular}{|c|c|c|c|c|c|}
\hline & $\begin{array}{l}\text { (1) } \\
\text { All }\end{array}$ & $\begin{array}{c}\text { (2) } \\
\text { Private sector }\end{array}$ & $\begin{array}{c}\text { (3) } \\
\text { Public sector }\end{array}$ & $\begin{array}{l}(4) \\
\text { Men }\end{array}$ & $\begin{array}{c}(5) \\
\text { Women }\end{array}$ \\
\hline Union & .094 & .052 & .127 & .035 & .147 \\
\hline & $(28.07)$ & $(11.41)$ & $(24.54)$ & $(7.25)$ & $(31.73)$ \\
\hline Age & .066 & .068 & .053 & .088 & .046 \\
\hline & $(94.43)$ & $(84.34)$ & (35.89) & $(85.55)$ & $(48.90)$ \\
\hline $\mathrm{Age}^{2}$ & -.0007 & -.0007 & -.0006 & -.0009 & -.0005 \\
\hline & $(82.43)$ & $(73.25)$ & $(31.91)$ & (74.99) & $(43.10)$ \\
\hline Male & $\begin{array}{r}.181 \\
(55.90)\end{array}$ & $\begin{array}{r}.195 \\
(49.81)\end{array}$ & $\begin{array}{r}.158 \\
(28.20)\end{array}$ & $\mathrm{n} / \mathrm{a}$ & $\mathrm{n} / \mathrm{a}$ \\
\hline Black Caribbean & $\begin{array}{c}-.076 \\
(4.61)\end{array}$ & $\begin{array}{c}-.116 \\
(5.26)\end{array}$ & $\begin{array}{c}-.020 \\
(0.85)\end{array}$ & $\begin{array}{r}-.128 \\
(4.87)\end{array}$ & $\begin{array}{l}-.047 \\
(2.27)\end{array}$ \\
\hline Black - African & $\begin{array}{r}-.191 \\
(7.67)\end{array}$ & $\begin{array}{r}-.189 \\
(5.81)\end{array}$ & $\begin{array}{r}-.186 \\
(5.17)\end{array}$ & $\begin{array}{r}-.272 \\
(7.27)\end{array}$ & $\begin{array}{l}-.134 \\
(4.12)\end{array}$ \\
\hline Black - other & $\begin{array}{l}-.122 \\
(3.30)\end{array}$ & $\begin{array}{r}-.105 \\
(2.11)\end{array}$ & $\begin{array}{l}-.133 \\
(2.55)\end{array}$ & $\begin{array}{r}-.210 \\
(3.75)\end{array}$ & $\begin{array}{l}-.072 \\
(1.49)\end{array}$ \\
\hline Indian & $\begin{array}{l}-.101 \\
(7.96)\end{array}$ & $\begin{array}{r}-.122 \\
(8.23)\end{array}$ & $\begin{array}{r}-.045 \\
(1.85)\end{array}$ & $\begin{array}{r}-.094 \\
(5.23)\end{array}$ & $\begin{array}{l}-.107 \\
(6.05)\end{array}$ \\
\hline Pakistani & $\begin{array}{r}-.110 \\
(4.94)\end{array}$ & $\begin{array}{r}-.165 \\
(6.43)\end{array}$ & $\begin{array}{r}.067 \\
(1.57)\end{array}$ & $\begin{array}{r}-.143 \\
(4.91)\end{array}$ & $\begin{array}{l}-.043 \\
(1.28)\end{array}$ \\
\hline Bangladeshi & $\begin{array}{r}-.264 \\
(6.09)\end{array}$ & $\begin{array}{r}-.395 \\
(7.89)\end{array}$ & $\begin{array}{r}-.121 \\
(1.43)\end{array}$ & $\begin{array}{r}-.364 \\
(6.86)\end{array}$ & $\begin{array}{r}.005 \\
(0.07)\end{array}$ \\
\hline Chinese & $\begin{array}{r}-.033 \\
(0.99)\end{array}$ & $\begin{array}{r}-.018 \\
(0.46)\end{array}$ & $\begin{array}{r}-.067 \\
(1.12)\end{array}$ & $\begin{array}{r}-.076 \\
(1.39)\end{array}$ & $\begin{array}{l}.010 \\
(0.25)\end{array}$ \\
\hline Other race & $\begin{array}{r}-.030 \\
(1.98)\end{array}$ & $\begin{array}{r}-.021 \\
(1.17)\end{array}$ & $\begin{array}{r}-.034 \\
(1.38)\end{array}$ & $\begin{array}{r}-.049 \\
(2.19)\end{array}$ & $\begin{array}{l}-.022 \\
(1.10)\end{array}$ \\
\hline 11-19 employees & $\begin{array}{r}.082 \\
(14.51)\end{array}$ & $\begin{array}{r}.076 \\
(11.74)\end{array}$ & $\begin{array}{r}.078 \\
(6.44)\end{array}$ & $\begin{array}{r}.101 \\
(11.24)\end{array}$ & $\begin{array}{c}.060 \\
(8.47)\end{array}$ \\
\hline 20-24 employees & $\begin{array}{r}.091 \\
(12.18)\end{array}$ & $\begin{array}{r}.083 \\
(9.35)\end{array}$ & $\begin{array}{r}.080 \\
(5.68)\end{array}$ & $\begin{array}{r}.106 \\
(8.98)\end{array}$ & $\begin{array}{r}.072 \\
(7.57)\end{array}$ \\
\hline Don't know but $<25$ & $\begin{array}{r}.040 \\
(3.38)\end{array}$ & $\begin{array}{r}.031 \\
(2.25)\end{array}$ & $\begin{array}{r}.049 \\
(2.06)\end{array}$ & $\begin{array}{r}.066 \\
(3.82)\end{array}$ & $\begin{array}{l}.003 \\
(0.16)\end{array}$ \\
\hline 25-49 employee & $\begin{array}{r}.118 \\
(22.34)\end{array}$ & $\begin{array}{r}.116 \\
(18.82)\end{array}$ & $\begin{array}{r}.090 \\
(8.32)\end{array}$ & $\begin{array}{r}.135 \\
(16.64)\end{array}$ & $\begin{array}{r}.096 \\
(14.05)\end{array}$ \\
\hline Don't know but >24 & $\begin{array}{r}.083 \\
(6.49)\end{array}$ & $\begin{array}{r}.084 \\
(5.37)\end{array}$ & $\begin{array}{r}.049 \\
(2.06)\end{array}$ & $\begin{array}{r}.100 \\
(5.66)\end{array}$ & $\begin{array}{l}.062 \\
(3.42)\end{array}$ \\
\hline$>=50$ employees & $\begin{array}{r}.177 \\
(43.03)\end{array}$ & $\begin{array}{r}.183 \\
(38.83)\end{array}$ & $\begin{array}{r}.127 \\
(13.99)\end{array}$ & $\begin{array}{r}.203 \\
(31.93)\end{array}$ & $\begin{array}{r}.149 \\
(28.49)\end{array}$ \\
\hline $\mathrm{N}$ & 105,112 & 75,000 & 29,712 & 51,544 & 53,568 \\
\hline $\mathrm{R}^{2}$ & .4537 & .4524 & .4256 & .4487 & .4273 \\
\hline Adjusted $\mathrm{R}^{2}$ & .4530 & .4514 & .4230 & .4472 & .4259 \\
\hline
\end{tabular}

Notes: All equations also include time, 40 schooling dummies, 19 region dummies and 60 industry dummies. Excluded categories are 1-10 employees and white. Private sector excludes the self-employed. $|\mathrm{t}|$-statistics are given in parentheses.

Source: Labour Force Survey files. 
Appendix Table 5

Log hourly earnings equations for Britain, 1985-2001

\begin{tabular}{|c|c|c|c|c|c|}
\hline & $\begin{array}{c}(1) \\
\text { All sectors }\end{array}$ & $\begin{array}{c}\text { (2) } \\
\text { Private sector }\end{array}$ & $\begin{array}{c}\text { (3) } \\
\text { Public sector }\end{array}$ & $\begin{array}{l}(4) \\
\text { Men }\end{array}$ & $\begin{array}{c}(5) \\
\text { Women }\end{array}$ \\
\hline \multirow[t]{2}{*}{ Union } & .087 & .069 & .095 & .059 & .106 \\
\hline & (12.30) & $(6.50)$ & (6.69) & (6.29) & (9.88) \\
\hline \multirow{2}{*}{ Age $25-34$} & .272 & .280 & .258 & .310 & .239 \\
\hline & $(23.83)$ & (19.59) & (11.27) & (19.85) & (14.37) \\
\hline \multirow{2}{*}{ Age $35-44$} & .363 & .374 & .335 & .455 & .276 \\
\hline & (30.61) & $(24.90)$ & (14.41) & (28.54) & (15.76) \\
\hline \multirow[t]{2}{*}{ Age 45-54 } & .370 & .377 & . 362 & . 462 & .281 \\
\hline & $(29.73)$ & $(23.42)$ & $(15.22)$ & $(27.34)$ & $(15.43)$ \\
\hline \multirow[t]{2}{*}{ Age 55 or more } & .375 & .384 & .339 & .427 & .309 \\
\hline & $(24.91)$ & (19.43) & (12.02) & $(22.20)$ & (13.18) \\
\hline \multirow[t]{2}{*}{ Female } & -.261 & -.286 & -.240 & $\mathrm{n} / \mathrm{a}$ & $\mathrm{n} / \mathrm{a}$ \\
\hline & (34.44) & (26.98) & (18.46) & & \\
\hline \multirow[t]{2}{*}{ Full-time } & .126 & .169 & .064 & .021 & . 127 \\
\hline & (10.99) & (10.31) & $(3.46)$ & $(0.51)$ & (10.38) \\
\hline \multirow{2}{*}{ Manual } & -.255 & -.250 & -.277 & -.287 & -.225 \\
\hline & $(29.55)$ & $(22.53)$ & (16.09) & $(25.38)$ & (16.59) \\
\hline \multirow[t]{2}{*}{ 10-24 employees } & .108 & .089 & .081 & .082 & .123 \\
\hline & (7.98) & (5.35) & (2.63) & (4.34) & (6.58) \\
\hline \multirow[t]{2}{*}{ 25-99 employees } & .146 & .159 & .063 & .141 & .151 \\
\hline & (12.02) & (10.48) & $(2.20)$ & $(8.28)$ & $(8.88)$ \\
\hline \multirow[t]{2}{*}{ 100-499 employees } & .182 & .211 & .097 & .205 & .158 \\
\hline & (14.56) & (13.46) & (3.35) & (11.85) & (8.88) \\
\hline \multirow{2}{*}{500 or more employees } & .257 & .317 & .117 & .279 & .231 \\
\hline & (19.38) & (17.94) & $(4.02)$ & $(15.40)$ & (12.05) \\
\hline \multirow[t]{2}{*}{ Manufacturing } & .062 & .047 & .115 & .067 & .044 \\
\hline & (7.55) & $(4.74)$ & $(3.08)$ & $(7.07)$ & $(2.87)$ \\
\hline $\mathrm{N}$ & 17,934 & 10,463 & 4,748 & 8,969 & 8,965 \\
\hline $\mathrm{R}^{2}$ & .51 & .53 & .55 & .50 & .49 \\
\hline
\end{tabular}

Notes: All equations also include 5 categorical time dummies, 7 highest qualification dummies, and 6 region dummies. Excluded categories are aged 18-25 years and 1-9 employees. Confined to employees in employment working 10 or more hours per week. Public/private sector status unavailable in 1994/95, so these two years are excluded from the public and private sector equations. $|\mathrm{t}|$-statistics are given in parentheses.

Source: British Social Attitudes Surveys 1985-2001. 


\section{Endnotes}

1 Some of the estimates are for Great Britain which, unlike the UK, excludes Northern Ireland. Estimates are similar whichever geographical area is chosen.

2 We have no micro-data since 2001 when labour markets loosened and the unemployment rate started to rise again in the United States.

3 Wessels (1994) has cogently argued that OLS will not necessarily provide an upper limit estimate. His argument is that, provided a union has a certain degree of bargaining power, union-won increases in the wage that lead the firm to hire more able workers will be followed by further union actions to raise the wage. Knowing this and given repeated bargains, the firm will not necessarily hire more able workers.

4 Kaufman (2002) discusses the extent to which this empirical work on union wage determination fits the various economic models of union wage determination that have been developed since the work of Dunlop and Ross. His conclusion is pessimistic.

5 See Blanchflower (1984, 1986), Stewart (1987), Blanchflower and Oswald (1990), Blanchflower, Oswald and Garrett (1990), Stewart (1990, 1991, 1995), Metcalf and Stewart (1992), Machin, Stewart, and Van Reenen (1993), Blanchflower and Machin (1996), Forth and Millward (2000b).

6 See Stewart (1983), Shah (1984), Green (1988), Symons and Walker (1988), Blackaby, Yaron (1990), Murphy, and Sloane (1991), Blanchflower (1991), Main and Reilly (1992), Murphy, Sloane, and Blackaby (1992), Main (1996), Lanot and Walker (1998), Andrews et al. (1998), Andrews, Bell and Upward (1998), Blanchflower (1999), Hildreth (1999, 2000), Forth and Millward (2000a), Millward, Forth, and Bryson (2001), Swaffield (2001), Machin (2001), Booth and Bryan (2001), Bryson (2002), Forth and Millward (2002).

${ }^{7}$ Unfortunately the BHPS data file is very small in size with only around 4,000 workers present in consecutive waves and hence there are very few individuals that change status from year to year. This means there are severe limitations to using BHPS to compare the sensitivity of union wage gap estimates to differences in methodology as in Andrews et al. (1998).

8 Source: Statistical Abstract of the US, 2002, Table no. 567 downloadable at http://www.census.gov/prod/2002pubs/01statab/stat-ab01.html

9 Source: UK Office of National Statistics. Downloadable from http://www.statistics.gov.uk/statbase/TSDtimezone.asp

${ }^{10}$ Freeman (1995) and Mishel and Bernstein (1994) report declines of this magnitude.

${ }^{11}$ For more information on changes in real wages, see OECD (1996) and Katz, Loveman, and Blanchflower (1995) for the UK, the US, France and Japan. 
${ }^{12}$ See OECD (1996).

13 Interestingly enough, Canada with many of the same firms and trade unions as the US has not seen declines in density: $1970=31 \%, 1980=36.1 \% ; 1990=35.8 \% ; 1993=37.4 \%$ (see Visser, 1996).

${ }^{14}$ We thank Mark Wooden for providing us with these numbers.

15 Further examples of studies for Canada are Simpson (1985), who found 11\% for 1974; Grant, Swidinsky, and Vanderkamp (1987) who reported 12-14\% for 1969 and 13-16\% for 1970.

${ }^{16}$ Australian studies include Kornfeld (1993), who found 7-10\% for young people between 1984 and 1987; Mulvey (1986), who obtained estimates of $7 \%$ for women and $10 \%$ for men using a 1982 sample; Christie (1992) who obtained an estimate of 16.6\% using OLS and $17.2 \%$ using simultaneous equation methods with 1984 data; and Blanchflower and Freeman (1992) who report $8 \%$ for the period $1985-87$.

${ }^{17}$ In footnote 36 below we make use of individual level data from a similar survey undertaken in the UK, namely, the 1998 Workplace Employee Relations Survey.

${ }^{18}$ In Blanchflower (1996) union wage gap estimates were obtained based on similar data and specifications for the following countries (where * indicates not significantly different from zero):

$\begin{array}{lc} & \% \\ \text { Australia } & 9.2 \\ \text { Austria } & 14.6 \\ \text { Canada } & 4.8^{*} \\ \text { Germany } & 3.4 \\ \text { Ireland } & 30.5 \\ \text { Israel } & 7.0^{*} \\ \text { Italy } & 7.2 \\ \text { Japan } & 47.8 \\ \text { Netherlands } & 3.7^{*} \\ \text { New Zealand } & 8.4 \\ \text { Norway } & 7.7 \\ \text { Spain } & 0.3^{*} \\ \text { Switzerland } & 0.8^{*}\end{array}$

The very large estimate for Japan appears to arise because of the lack of controls for workplace/firm size. Some of the estimates are based on only a few hundred observations and so care has to be taken in interpreting these results.

19 Details of the ISSP surveys, data and manuals are available at www.issp.org. The data files are also available through ICPSR at the University of Michigan at http://www.icpsr.umich.edu. 
20 Troy (2000) has argued that union density in Canada has remained as high as it has due to the expanded role of the public sector and quasi-public sector organizations (particularly in health care). Troy shows that private sector density - in contrast to that in the public sector - has declined albeit at a somewhat slower rate than in the US.

${ }^{21}$ The May extracts of the CPS extracts in Stata format from 1969-1987 are available from the NBER at http://www.nber.org/data/cps_may.html

22 Hirsch, Macpherson, and Schumacher (2002) have compared union wage gap estimates obtained from the BLS quarterly Employment Cost Index (ECI) constructed from establishment surveys and from the annual Employer Costs for Employee Compensation (ECEC) with those obtained using the CPS. They find that union/non-union wage trends in the three series 'are consistent neither with each other nor with the CPS', and ultimately conclude that 'we find ourselves relying most heavily on results drawn from the CPS' (Hirsch, Macpherson, and Schumacher, 2002, p.23).

23 There was no CPS survey with wages and union status in 1982.

24 Following Mincer, it is more usual to include a term in potential experience rather than a direct measure of age. We use education, however, for reasons of comparability as the CPS Outgoing Rotation Group files from 1993 report qualifications rather than years of schooling.

25 We do not deal here with a further problem identified by Card (1996) of misclassification of self-reported union status in the CPS, first identified by Mellow and Sider (1983). Card concludes that about $2.7 \%$ are false positives and $2.7 \%$ are false negatives. Given that there are more non-union workers than union workers, this means the union density rate is biased upwards. See Farber (2001) for a discussion and a procedure to adjust the union density rate for error. In 1998, the observed private sector rate of 9.7\% translates to an adjusted rate of $7.4 \%$ (the figures for 1973 were $25.9 \%$ and $24.5 \%$ respectively).

26 The number of wage observations followed by the percentage imputed in parentheses (hourly + non-hourly paid) in the NBER MORG are given below. Note in 1995 allocation information is only available on one-third of wage observations, hence the small sample.

$\begin{array}{llllllll}1979 & 171,745(16.5 \%) & 1986 & 179,147(10.7 \%) & 1993 & 174,595(4.6 \%) & 2000 & 161,126(29.8 \%) \\ 1980 & 199,469(15.8 \%) & 1987 & 180,434(13.5 \%) & 1994 & 170,865(0 \%) & 2001 & 171,533(30.9 \%) \\ 1981 & 186,923(15.2 \%) & 1988 & 173,118(14.4 \%) & 1995 & 55,967(23.3 \%) & & \\ 1982 & 175,797(13.7 \%) & 1989 & 176,411(3.7 \%) & 1996 & 152,190(22.2 \%) & & \\ 1983 & 173,932(13.8 \%) & 1990 & 185,030(3.9 \%) & 1997 & 154,955(22.2 \%) & & \\ 1984 & 177,248(14.7 \%) & 1991 & 179,560(4.4 \%) & 1998 & 156,990(23.6 \%) & & \\ 1985 & 180,232(14.3 \%) & 1992 & 176,848(4.2 \%) & 1999 & 159,362(27.6 \% & & \end{array}$

27 We thank Barry Hirsch for helpful discussions on these issues. All errors are ours of course and not his!

28 Bratsberg and Ragan (2002) found an average premium in the private sector of $16.8 \%, 1971$ 99, using a set of control variables similar to those used by Hirsch and Schumacher (2002). 
29 There was essentially no difference in the results when two-digit occupation dummies were replaced with three- digit dummies (results not reported).

30 There is a dissonance between the estimates Lewis offers by way of summary in his introductory chapter and those given in his Table 9.7 which are produced here (Lewis, 1986, p. 9)

${ }^{31}$ Lewis (1986) had 35 studies using the CPS, 1970-1979; 16 studies using the 1967 Survey of Economic Opportunity; 25 studies using the Panel Study of Income Dynamics, 1967-78; 15 studies using Michigan Survey Research Center survey data other than the PSID, including the 1972-73 Quality of Employment Survey; 22 studies using the National Longitudinal Surveys of 1969-72; and 8 studies exploiting other sources.

32 Full equations for the US as a whole as well as disaggregations by gender and broad sector are reported in Appendix Table 3.

33 Even activism on this scale would yield a steady state private sector unionisation rate of just 6.4\% (Farber and Western, 2001, p. 27).

${ }^{34}$ For further discussion on this point, see Blanchflower and Freeman (1992).

35 Blanchflower (1999) estimated union wage premia for the UK using the same methods as used here for the period 1983-94 using data from the same sources as used here plus the British Household Panel Survey for 1991-93 and the 1983 General Household Survey and found evidence of a constancy of the differential at approximately $10 \%$.

${ }^{36}$ Further support for the proposition that the BSAS 1997 point estimate is an outlier comes from the authors' calculations of the log hourly wage premium using the same methodology (unweighted estimates of the mid-point earnings) for individual level data from the Workplace Employee Relations Survey 1998, the fieldwork for which spanned 1997 and 1998. The raw membership premium is $.226(25.4 \%)$. This shifts with the addition of controls as follows: + demographics $=.121 ;+$ job $=.114 ;+$ establishment $=.076 ;+$ geographical $=.091$. In short, these estimates also point to a premium of around 10\% in 1997/98.

${ }^{37}$ Full equations for the economy as a whole, private and public sectors, and for men and women are reported in Appendix Table 4.

${ }^{38}$ Full equations for the economy as a whole, private and public sectors, and for men and women are reported in Appendix Table 5. 